\title{
A Bond-Weakening Borinate Catalyst that Improves the Scope of the Photoredox $\alpha-\mathrm{C}-\mathrm{H}$ Alkylation of Alcohols
}

\author{
Kentaro Sakai \\ Kounosuke Oisaki* (d) \\ Motomu Kanai* (1)
}

Graduate School of Pharmaceutical Sciences, The University of Tokyo, 7-3-1 Hongo, Bunkyo-ku, Tokyo 113-0033, Japan oisaki@mol.f.u-tokyo.ac.jp

kanai@mol.f.u-tokyo.ac.jp

Dedicated to the late Professor Dieter Enders

Received: 14.02.2020

Accepted after revision: 06.04.2020

Published online: 12.05 .2020

DOI: 10.1055/s-0040-1707114; Art ID: ss-2020-z0092-fa

Abstract The development of catalyst-controlled, site-selective $\mathrm{C}\left(\mathrm{sp}^{3}\right)-\mathrm{H}$ functionalization reactions is currently a major challenge in organic synthesis. In this paper, a novel bond-weakening catalyst that recognizes the hydroxy group of alcohols through formation of a borate is described. An electron-deficient borinic acid-ethanolamine complex enhances the chemical yield of the $\alpha-\mathrm{C}-\mathrm{H}$ alkylation of alcohols when used in conjunction with a photoredox catalyst and a hydrogen atom transfer catalyst under irradiation with visible light. This ternary hybrid catalyst system can, for example, be applied to functional-groupenriched peptides.

Key words photoredox catalyst, hydrogen atom transfer catalyst, boron, bond-weakening, $\mathrm{C}-\mathrm{H}$ functionalization

Novel $\mathrm{C}-\mathrm{H}$ functionalization reactions enable not only innovative concise synthetic routes, but also the late-stage functionalization of complex molecules, thus accelerating the discovery of functional materials and medicinal lead compounds. ${ }^{1,2}$ In particular, $\mathrm{C}\left(\mathrm{sp}^{3}\right)-\mathrm{H}$ functionalizations have shown great potential in drug discovery, as such reactions facilitate the derivatization of $\mathrm{sp}^{3}$-rich carbon skeletons, which is advantageous in order to enhance success rates in clinical trials. ${ }^{3}$

Recently, hybrid catalyst systems that consist of a photoredox catalyst (PC) and a hydrogen atom transfer (HAT) catalyst have attracted significant attention from the synthetic chemistry community, including our group. ${ }^{4,5}$ PCHAT hybrid catalysts generally functionalize unactivated $\mathrm{C}\left(\mathrm{sp}^{3}\right)-\mathrm{H}$ bonds under mild conditions with high functional group tolerance. Most reported PC-HAT hybrid catalysts exhibit innate selectivity: The $\mathrm{C}-\mathrm{H}$ bond with the lowest bond-dissociation energy (BDE) or the most hydridic $\mathrm{C}-\mathrm{H}$ bond in the substrate are preferentially converted. Thus, the

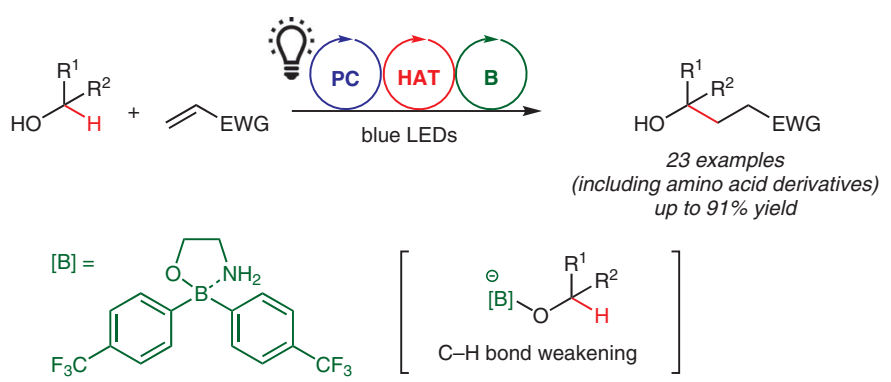

development of catalyst-controlled, site-selective $\mathrm{C}\left(\mathrm{sp}^{3}\right)-\mathrm{H}$ functionalization reactions remains a formidable challenge.

One promising strategy to realize catalyst-controlled site-selectivity is the use of bond-weakening catalysis (Scheme 1, a). The weakening of $\mathrm{N}-\mathrm{H}$ and $\mathrm{O}-\mathrm{H}$ bonds via coordination to low-valent metal complexes has been studied in the area of inorganic chemistry. ${ }^{6}$ The application of

(a) Bond-weakening catalyst in conjunction with a PC-HAT hybrid system

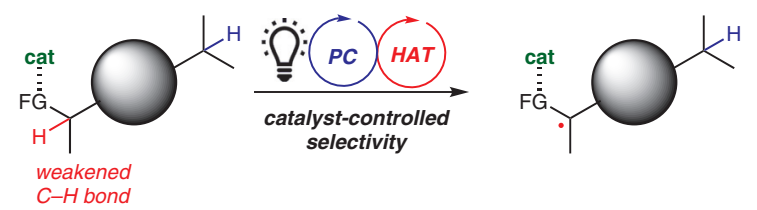

(b) Precedents of bond-weakening effects in conjunction with a PC-HAT hybrid system

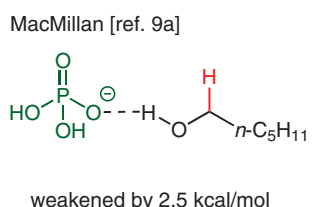

weakened by $2.5 \mathrm{kcal} / \mathrm{mol}$

Oisaki and Kanai [ref. 5c]

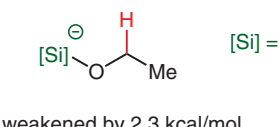

weakened by $2.3 \mathrm{kcal} / \mathrm{mol}$

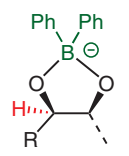

weakened by $4.2-4.5 \mathrm{kcal} / \mathrm{mol}$ limited to cis-1,2-diols (c) Bond-weakening effects of borate formation supported by DFT calculations

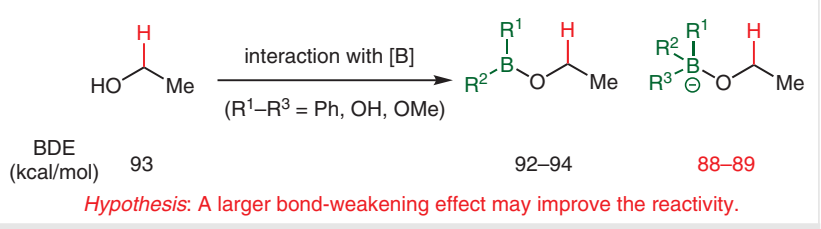

Scheme 1 Strategies for $\mathrm{C}\left(\mathrm{sp}^{3}\right)-\mathrm{H}$ functionalization reactions based on a bond-weakening catalyst with a PC-HAT system 
this phenomenon to synthetic organic chemistry has provided a new design principle for the molecular engineering of synthetic catalysts. ${ }^{7,8}$ However, the oxidizing nature of conventional PC-HAT hybrid systems is often incompatible with low-valent metal complexes; instead, a redox-metalfree bond-weakening system would be preferable to use in conjunction with a PC-HAT hybrid system.

There have been previous reports of the use of bondweakening catalysts in conjunction with PC-HAT hybrid systems to promote the selective $\alpha-\mathrm{C}-\mathrm{H}$ alkylation of alcohols (Scheme 1, b). ${ }^{5 c, 9,10}$ Seminal work has been reported by MacMillan and co-workers, ${ }^{9 a}$ who used dihydrogen phosphate as a hydrogen-bonding-acceptor catalyst to accelerate the $\mathrm{C}-\mathrm{H}$ alkylation of alcohols. The same catalytic system was applied to the site-selective modification of carbohydrates by Minnaard and co-workers. ${ }^{9 b}$ Recently, this methodology was used for the synthesis of rare sugar isomers through site-selective epimerization by Wendlandt and co-workers. ${ }^{9 \mathrm{c}}$ Taylor and co-workers have reported the use of borinic acid ${ }^{10 a}$ and boronic acid ${ }^{10 b}$ bond-weakening catalysts in conjunction with PC-HAT hybrid systems to realize the site-selective $\mathrm{C}-\mathrm{H}$ alkylation and redox isomerization of carbohydrates, respectively. In these reactions, the formation of cyclic borates between the boron catalysts and the cis-1,2-diol moiety of the carbohydrates plays a key role. Recently, our group has reported that Martin's spirosilane ${ }^{11}$ can act as a bond-weakening catalyst by forming a silicate to promote the $\mathrm{C}-\mathrm{H}$ alkylation of alcohols. ${ }^{5 \mathrm{c}}$ Based

\section{Biographical Sketches}
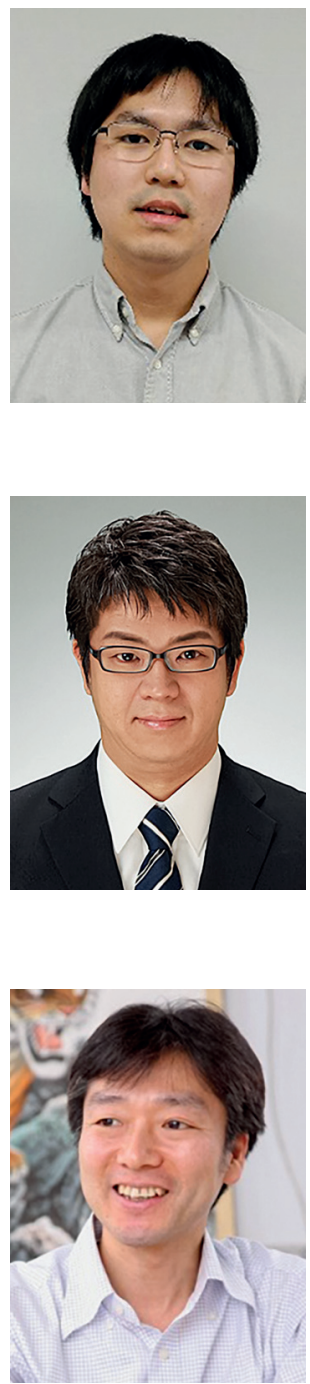

Kentaro Sakai was born in 1994 and raised in Tochigi, Japan. He obtained his bachelor's degree (2017) and master's degree (2019) under the direction

Kounosuke Oisaki was born in 1980 in Tokushima, Japan, and received his Ph.D. from The University of Tokyo (UTokyo) in 2008 under the direction of Professor Masakatsu Shibasaki. He then moved to the University of California-Los Angeles, USA, for postdoctoral studies with Professor Omar M. Yaghi. In 2010, he returned to Japan and joined

Motomu Kanai received his bachelor's degree from The University of Tokyo (UTokyo) in 1989 under the direction of the late Professor Kenji Koga. He obtained an assistant professor position at Osaka University under the direction of Professor Kiyoshi Tomioka in 1992. He obtained his Ph.D. from Osaka University in 1995, and then moved to the University of Wisconsin, USA, for postdoctoral studies with Professor Laura L. Kiessling. In 1997, he returned of Professor Motomu Kanai at The University of Tokyo. He is currently a Ph.D. student at the Graduate School of Pharmaceutical Sciences, The University of
Tokyo. His current research focuses on the development of a new methodology for selective $\mathrm{C}\left(\mathrm{sp}^{3}\right)-\mathrm{H}$ functionalization under visible-light irradiation.
Professor Motomu Kanai's group at UTokyo as an assistant professor. He is currently working as a lecturer (since 2016). He has received The Pharmaceutical Society of Japan Award for Young Scientists (2018), the Mitsui Chemicals Catalysis Science Award of Encouragement (2018), the Chemist Award BCA (2018), and the Thieme Chem-

to Japan and joined Professor Masakatsu Shibasaki's group at UTokyo as an assistant professor. After working as a lecturer (2000-2003) and an associate professor (2003-2010), he became a professor at UTokyo in 2010. He served as a principle investigator at ERATO Kanai Life Science Project (2011-2017), and is currently the head investigator of MEXT Grant-in-Aid for Scientific Research on Innovative Areas, 'Hybrid Catalysis' (2017-2022). He is a recipient istry Journals Award (2019). His current research interest is directed toward the development of new synthetic organic chemistry, with a focus on organoradical-based chemoselective reagents/catalysis for $\mathrm{C}\left(\mathrm{sp}^{3}\right)-\mathrm{H}$ functionalizations and peptide/ protein modifications.

of The Pharmaceutical Society of Japan Award for Young Scientists (2001), the Thieme Journals Award (2003), the MerckBanyu Lectureship Award (MBLA) (2005), the Asian Core Program Lectureship Award (2008 and 2010, from Thailand, Malaysia, and China), the Thomson Reuters 4th Research Front Award (2016), and the Nagoya Silver Medal (2020). His research interests encompass the design and synthesis of functional molecules. 
on DFT calculations, the bond-weakening effect of the silicate was estimated to be $2.3 \mathrm{kcal} / \mathrm{mol}^{.5 \mathrm{c}}$ The same calculations indicated that the BDEs of the alcohol $\alpha-\mathrm{C}-\mathrm{H}$ bonds were reduced by $4-5 \mathrm{kcal} / \mathrm{mol}$ through the formation of anionic borates; this reduction was greater than those induced by silicates or hydrogen-bonding catalysts. ${ }^{12}$ The formation of neutral boron ester species, however, did not show a bond-weakening effect (Scheme 1, c). Thus, we hypothesized that a PC-HAT-borate hybrid catalyst system could result in higher reactivity and a broader substrate scope for the $\alpha-C-H$ alkylation of mono-alcohols compared to those of the previously reported dihydrogen phosphate and silicate systems due to the greater bond-weakening ability of the in situ generated anionic borate species. In the present study, we have identified an electron-deficient borinic acid-ethanolamine complex as a novel $\mathrm{C}-\mathrm{H}$ bondweakening catalyst for mono-alcohols. The system was found to be applicable to amino acid derivatives, which were not accessible under the conditions applied in previous studies.

To develop the boron-catalyzed $\alpha-\mathrm{C}-\mathrm{H}$ alkylation of simple mono-alcohols, we first screened various boron catalysts in the presence of the commonly used PC $\left[\operatorname{Ir}\left(\mathrm{dF}\left(\mathrm{CF}_{3}\right) \mathrm{ppy}\right)_{2}(\mathrm{dtbpy})\right]\left[\mathrm{PF}_{6}\right](\mathbf{4 a})^{13}$ and the HAT catalyst quinuclidine (5a) ${ }^{9 a-c, 10,14}$ (Table 1). Vinyl diethyl phosphonate (1a) and ethanol (2a) were used as substrates. Under irradiation from blue LEDs without any boron additive, the desired C-H-alkylated product (3aa) was obtained in $28 \%$

Table 1 Optimization of the Boron Source ${ }^{\mathrm{a}}$

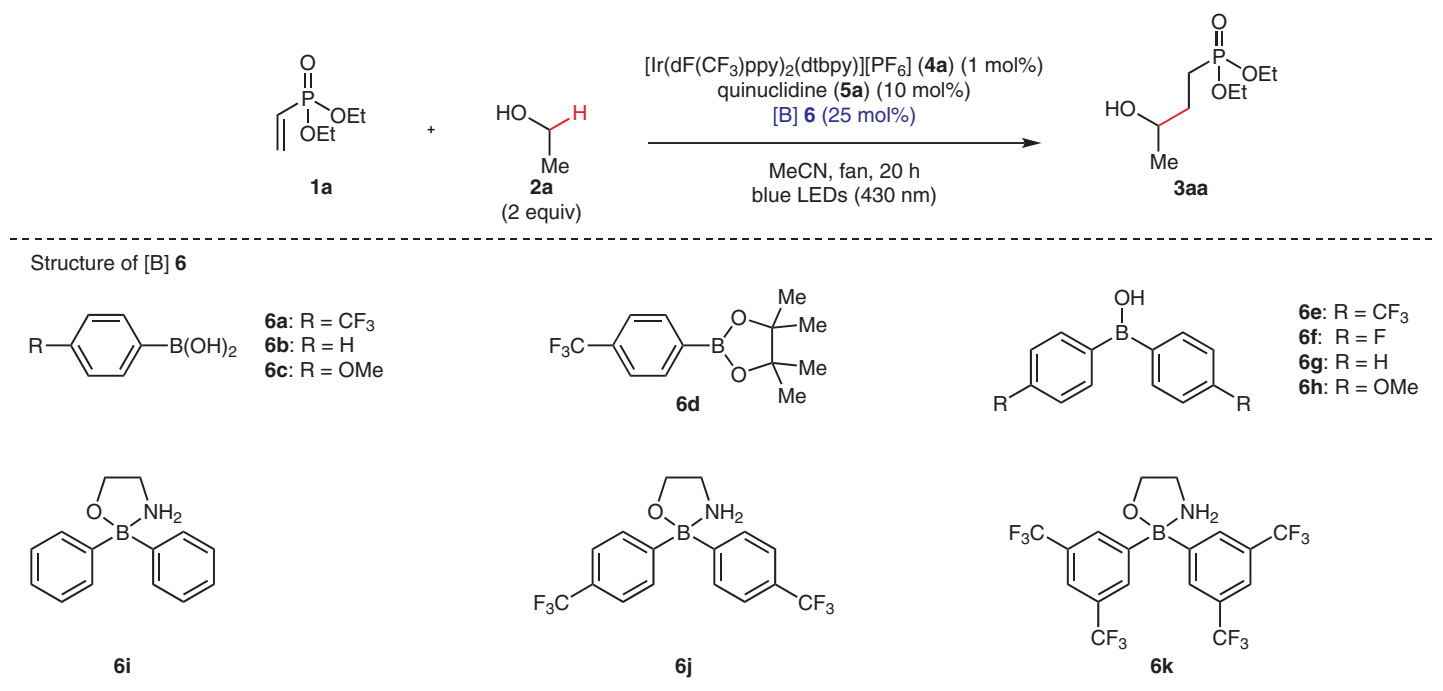

\begin{tabular}{|c|c|c|}
\hline Entry & {$[\mathrm{B}] 6$} & Yield (\%) ${ }^{\mathrm{b}}$ \\
\hline 1 & none & 28 \\
\hline 2 & $6 a$ & 72 \\
\hline 3 & $6 b$ & 40 \\
\hline 4 & $6 c$ & 8 \\
\hline 5 & 6d & 51 \\
\hline 6 & $6 e$ & 14 \\
\hline 7 & $6 f$ & 15 \\
\hline 8 & $6 \mathrm{~g}$ & 17 \\
\hline 9 & $6 \mathrm{~h}$ & 14 \\
\hline 10 & $6 i$ & 31 \\
\hline 11 & $6 j$ & $87(84)^{c}$ \\
\hline 12 & $6 k$ & 82 \\
\hline 13 & $\mathrm{~B}\left(\mathrm{C}_{6} \mathrm{~F}_{5}\right)_{3}(\mathbf{6 I})$ & 0 \\
\hline
\end{tabular}


yield (entry 1 ). We then added various boron catalysts to the reaction mixture and evaluated their acceleration effect (entries 2-13). The yield of 3aa changed dramatically depending on the electronic characteristics of the boronic acid (entries 2-4), with the electron-deficient boronic acid $\mathbf{6 a}$ leading to a yield of $72 \%$. In contrast, the electron-rich boronic acid $\mathbf{6 c}$ showed a detrimental effect on the yield (Table 1 , entry 4 ), probably due to inhibition of the activation of the HAT catalyst by the competitive single-electron oxidation of $\mathbf{6 c}$. $^{10 b, 15}$ The acceleration effect of the boronic acid pinacol ester $\mathbf{6 d}$ was smaller than that of acid form $\mathbf{6 a}$, which suggests that steric hindrance may hamper the formation of the borate (entry 5). Hoping to further enhance the acceleration effect, we screened various borinic acids, which are known to produce tetravalent borates more easily than boronic acids due to the higher Lewis acidity of the boron center. ${ }^{16}$ Contrary to our expectations, the addition of borinic acids $\mathbf{6 e - h}$ did not improve the yield, regardless of the substituents (entries 6-9). We hypothesized that this could be due to the relatively low chemical stability of the borinic acids. We then investigated chemically stable borinic acid-ethanolamine complex $\mathbf{6 i},{ }^{17}$ which bears a dynamically exchangeable amino-alcohol ligand (entry 10). Compared to borinic acid $\mathbf{6 g}$, the use of $\mathbf{6} \mathbf{i}$ led to a significantly improved yield (entry 8 vs 10). Based on the substitution effect observed for $\mathbf{6 a - c}$, we then used the electron-deficient

Table 2 Optimization of the PC and HAT Catalysts
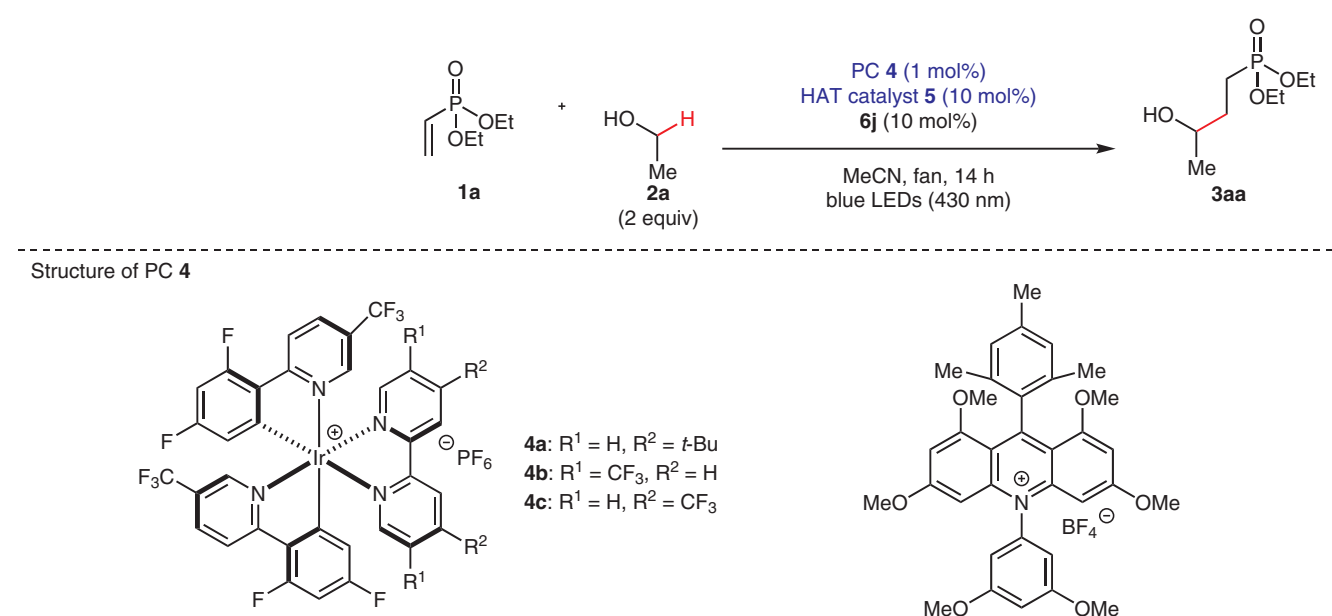

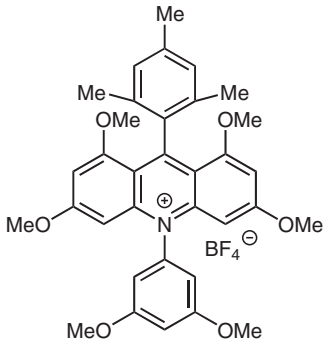

$4 d$

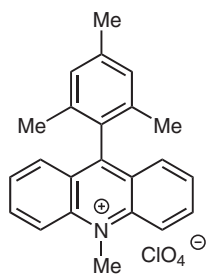

4 e

Structure of HAT catalyst 5

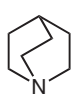

$5 a$

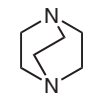

$5 b$

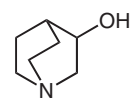

$5 c$

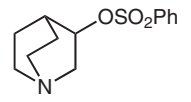

$5 d$

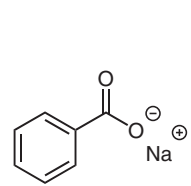

5 e

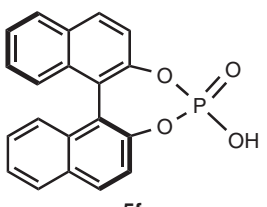

$5 f$

\begin{tabular}{cclc}
\hline Entry & PC & HAT catalyst & Yield (\%) \\
\hline 1 & $\mathbf{4 a}$ & $\mathbf{5 a}$ & 84 \\
2 & $\mathbf{4 b}$ & $\mathbf{5 a}$ & $\mathbf{5}$ \\
3 & $\mathbf{4 c}$ & $\mathbf{5 a}$ & $\mathbf{5 a}$ \\
4 & $\mathbf{4 d}$ & $\mathbf{5 a}$ & $\mathbf{5 a}$ \\
5 & $\mathbf{4 e}$ & $\mathbf{5 b}$ & 0 \\
6 & $\mathbf{4 a}$ & $\mathbf{5 c}$ & $\mathbf{5 0}$ \\
7 & $\mathbf{4 a}$ & $\mathbf{5 d}$ & $\mathbf{5 e}$ \\
9 & $\mathbf{4 a}$ & $\mathbf{5 f}$ & 0 \\
\hline
\end{tabular}

${ }^{a}$ Reaction conditions: acceptor 1a (1 equiv), EtOH (2a) (2 equiv), PC 4 (1 mol\%), HAT catalyst 5 (10 mol\%), $6 \mathbf{j}(10 \mathrm{~mol} \%), \mathrm{MeCN}\left([\mathbf{1 a}]_{\text {final }}=0.2 \mathrm{M}\right)$, blue LED irradiation; the temperature of the reaction $\left(25-33^{\circ} \mathrm{C}\right)$ was controlled for $14 \mathrm{~h}$ using a fan.

$\mathrm{b}$ The yield of 3 aa was determined by ${ }^{1} \mathrm{H}$ NMR analysis (internal standard: nitromethane). 
borinic acid-ethanolamine complex $\mathbf{6 j}$, which dramatically increased the yield of the $\mathrm{C}-\mathrm{H}$ alkylation ( $87 \%$ yield) (entry 11). Upon introduction of additional electron-deficient trifluoromethyl groups on the aromatic rings (6k), an acceleration effect that was merely similar to that of $\mathbf{6 j}$ was observed (entry 12). When we used tris(pentafluorophenyl)borane (61), the desired reaction was completely inhibited, which implies that the ligand exchange on the boron center is important for the $\mathrm{C}-\mathrm{H}$ alkylation (entry 13 ). Based on the aforementioned screening results, we identified $\mathbf{6 j}$ as the optimal boron catalyst. Further tuning of the reaction parameters confirmed that a comparable performance could be obtained when the reaction time was shortened to 14 hours and the loading of $\mathbf{6 j}$ was reduced to $10 \mathrm{~mol} \%$ (entry 11, yield in parentheses).

Next, we screened various PCs 4 (Table 2, entries 1-5). When we added organic dyes $4 d^{18}$ or $\mathbf{4} e^{19}$ instead of $\mathbf{4 a}$, almost none of the desired product was obtained (entries 4 and 5). The iridium photoredox catalysts $4 \mathbf{b}^{20}$ or $\mathbf{4} \mathbf{c}^{20}$ achieved $\mathrm{C}-\mathrm{H}$ alkylation (entries 2 and 3), albeit the yields were lower than that obtained with 4a. The lower reduction potential of $\mathbf{4 b} / \mathbf{4} \mathbf{c}$ compared to that of $\mathbf{4 a}\left[E_{1 / 2}\left(\mathrm{Ir}^{\mathrm{II}} / \mathrm{Ir}^{\mathrm{III}}\right)\right.$ $=-1.37 \mathrm{~V}$ for $\mathbf{4 a},-0.69 \mathrm{~V}$ for $\mathbf{4 b},-0.79 \mathrm{~V}$ for $\mathbf{4 c}$; all potentials vs SCE in $\mathrm{MeCN}]^{9 a, 20}$ might lead to inefficient catalyst regeneration; alternatively, the higher oxidation potential of $\mathbf{4 b} / \mathbf{4 c}\left[E\left(\mathrm{Ir}^{\mathrm{III}} / \mathrm{Ir}^{\mathrm{II}}\right)=+1.21 \mathrm{~V}\right.$ for $\mathbf{4 a},+1.68 \mathrm{~V}$ for $\mathbf{4 b},+1.65 \mathrm{~V}$ for

Table 3 Optimization of the Reaction Parameters ${ }^{\mathrm{a}}$

\begin{tabular}{|c|c|c|c|c|}
\hline 吾 & \multicolumn{3}{|c|}{$\begin{array}{c}{\left[\operatorname{Ir}\left(\mathrm{dF}\left(\mathrm{CF}_{3}\right) \mathrm{ppy}\right)_{2}(\mathrm{dtbpy})\right]\left[\mathrm{PF}_{6}\right](\mathbf{4 a})(1 \mathrm{~mol} \%)} \\
\text { quinuclidine }(5 \mathrm{a})(10 \mathrm{~mol} \%)\end{array}$} & OEt \\
\hline $\begin{array}{c}1 \mathbf{a} \\
\text { (x equiv) }\end{array}$ & $\begin{array}{c}\text { Me } \\
2 a \\
\text { (y equiv) }\end{array}$ & $\begin{array}{l}\text { solvent, fan, } 14 \mathrm{~h} \\
\text { blue LEDs }(430 \mathrm{~nm})\end{array}$ & & Maa \\
\hline Entry & Solvent & $\begin{array}{l}\text { Concentration } \\
{[\mathbf{1} \mathbf{a}]_{\text {final }}}\end{array}$ & $\begin{array}{l}\text { Ratio of } \\
1 \mathbf{a} / 2 \mathbf{a}\end{array}$ & Yield (\%) ${ }^{\mathrm{b}}$ \\
\hline 1 & $\mathrm{MeCN}$ & $0.2 \mathrm{M}$ & $1: 2$ & 84 \\
\hline 2 & DMSO & $0.2 \mathrm{M}$ & $1: 2$ & 80 \\
\hline 3 & acetone & $0.2 \mathrm{M}$ & $1: 2$ & 54 \\
\hline 4 & DMF & $0.2 \mathrm{M}$ & $1: 2$ & 31 \\
\hline 5 & DCM & $0.2 \mathrm{M}$ & $1: 2$ & 12 \\
\hline 6 & $\mathrm{PhCF}_{3}$ & $0.2 \mathrm{M}$ & $1: 2$ & 26 \\
\hline 7 & 1,4-dioxane & $0.2 \mathrm{M}$ & $1: 2$ & 15 \\
\hline 8 & $\mathrm{MeCN}$ & $0.2 \mathrm{M}$ & $1: 5$ & 89 \\
\hline 9 & $\mathrm{MeCN}$ & $0.2 \mathrm{M}$ & $1: 1$ & 74 \\
\hline 10 & $\mathrm{MeCN}$ & $0.2 \mathrm{M}\left([2 \mathrm{a}]_{\text {final }}\right)$ & $5: 1$ & 71 \\
\hline 11 & $\mathrm{MeCN}$ & $0.4 \mathrm{M}$ & $1: 2$ & 48 \\
\hline 12 & $\mathrm{MeCN}$ & $0.1 \mathrm{M}$ & $1: 2$ & 89 \\
\hline
\end{tabular}

a Blue LED irradiation; the temperature of the reaction $\left(25-33^{\circ} \mathrm{C}\right)$ was controlled for $14 \mathrm{~h}$ using a fan.

b The yield of 3aa was determined by ${ }^{1} \mathrm{H}$ NMR analysis (internal standard: nitromethane). 4c; all potentials vs SCE in $\mathrm{MeCN}]^{9 \mathrm{a}, 20}$ might lead to the decomposition of $\mathbf{6 j}$. We also screened several quinuclidine derivatives $(\mathbf{5 b}-\mathbf{d})^{5 c, 21}$ and other HAT catalysts $\left(\mathbf{5 e}^{22}\right.$ and $\mathbf{5} \mathbf{f}^{5 b}$ ). In these cases, the desired reaction did not proceed smoothly (entries 6-10).

After determining the optimal reagent combination (4a, $\mathbf{5 a}$ and $\mathbf{6 j}$ ), we further optimized the reaction parameters (Table 3). A solvent screening indicated that with the exception of DMF, which contains weak $\mathrm{C}-\mathrm{H}$ bonds, polar aprotic solvents showed good results (entries 1-4), and MeCN afforded the best result (entry 1 ). Less polar solvents such as $\mathrm{CH}_{2} \mathrm{Cl}_{2}$, benzotrifluoride, and 1,4-dioxane led to poor reactivity (entries 5-7). Next, we changed the ratio of substrates and the concentration (entries 8-12). The use of an excess of the alcohol (entry 1 vs 8 ) or a lower concentration of 1a (entry 1 vs 12) slightly improved the yield. On the other hand, an excess of the acceptor (entry 1 vs 10 ) or a higher concentration of 1a (entry 1 vs 11 ) had a negative effect on the yield. Based on this optimization process, we identified the conditions in entry 12 as being optimal.

Subsequently, we conducted control experiments (Table 4). In the absence of the PC or the HAT catalyst or the light source, 3aa was not obtained. Accordingly, the PC and HAT catalysts, as well as the blue light irradiation are essential for this reaction.

Table 4 Control Experiments ${ }^{\mathrm{a}}$

\begin{tabular}{|c|c|c|c|}
\hline${ }^{0}$ & \multicolumn{2}{|c|}{$\begin{array}{c}{\left[\operatorname{Ir}\left(\mathrm{dF}\left(\mathrm{CF}_{3}\right) \mathrm{ppy}\right)_{2}(\mathrm{dtbpy})\right]\left[\mathrm{PF}_{6}\right](\mathbf{4 a})(1 \mathrm{~mol} \%)} \\
\text { quinuclidine }(\mathbf{5 a})(10 \mathrm{~mol} \%)\end{array}$} & \multirow[b]{2}{*}{ 3aa } \\
\hline 1a & $\begin{array}{c}\mathrm{Me} \\
2 \mathrm{a} \\
\text { (2 equiv) }\end{array}$ & $\begin{array}{c}\text { MeCN, fan, } 14 \mathrm{~h} \\
\text { blue LEDs }(430 \mathrm{~nm})\end{array}$ & \\
\hline Entry & \multicolumn{2}{|c|}{ Variation from the 'standard' reaction conditions } & Yield (\%) \\
\hline 1 & \multicolumn{2}{|l|}{ none } & 89 \\
\hline 2 & \multicolumn{2}{|c|}{ absence of PC $4 a$} & 0 \\
\hline 3 & \multicolumn{2}{|c|}{ absence of HAT catalyst $\mathbf{5 a}$} & 0 \\
\hline 4 & \multicolumn{2}{|c|}{ absence of LED irradiation } & 0 \\
\hline \multicolumn{4}{|c|}{ 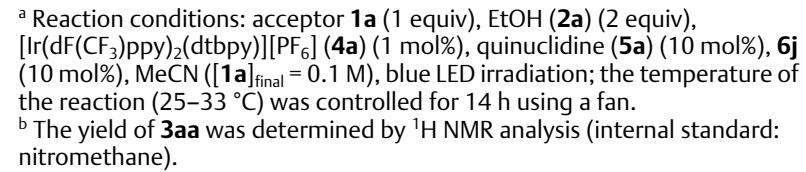 } \\
\hline
\end{tabular}

To obtain further insight into the operational mechanism of the boron catalyst, we examined its structureactivity relationship (Table 5 ). When borinic acid $\mathbf{6 e}$ was used, a smaller acceleration effect was observed, perhaps due to the insufficient chemical stability of $\mathbf{6 e}$ (entry 1 vs 2 ). The addition of only ethanolamine did not improve the yield (entry 3 vs 9). Next, we added borinic acid $\mathbf{6 e}$ and ethanolamine without pre-complexation to form $\mathbf{6 j}$. Although the yield was greatly improved (entry 4 vs 9 ), the improvement 
Table 5 Structure-Activity Relationship Study of the Boron Catalysts ${ }^{\mathrm{a}}$

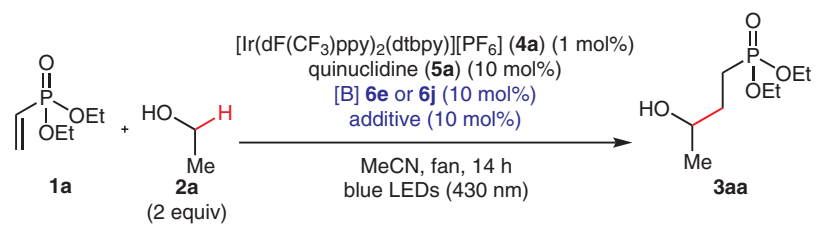

\begin{tabular}{|c|c|c|c|}
\hline Entry & {$[\mathrm{B}]$} & Additive & Yield (\%) ${ }^{\mathrm{b}}$ \\
\hline 1 & $6 \mathbf{j}$ & none & 89 \\
\hline 2 & 6e (borinic acid) & none & 51 \\
\hline 3 & none & & 25 \\
\hline 4 & 6e (borinic acid) & & 62 \\
\hline 5 & $6 e$ (borinic acid) & & 64 \\
\hline 6 & 6a (boronic acid) & none & 54 \\
\hline 7 & 6a (boronic acid) & & 32 \\
\hline 8 & 6a (boronic acid) & & 48 \\
\hline 9 & none & none & 32 \\
\hline \multicolumn{4}{|c|}{$\begin{array}{l}\text { a Reaction conditions: acceptor } 1 \mathrm{a}(1 \mathrm{equiv}) \text {, EtOH }(\mathbf{2 a})(2 \text { equiv), } \\
{\left[\mathrm{Ir}\left(\mathrm{dF}\left(\mathrm{CF}_{3}\right) \mathrm{ppy}\right)_{2}(\mathrm{dtbpy})\right]\left[\mathrm{PF}_{6}\right](\mathbf{4 a})(1 \mathrm{~mol} \%) \text {, quinuclidine }(\mathbf{5 a})(10 \mathrm{~mol} \%) \text {, }} \\
{[\mathrm{B}](\mathbf{6 e} \text { or } \mathbf{6 j})(10 \mathrm{~mol} \%) \text {, additive }(10 \mathrm{~mol} \%) \text {, MeCN }\left([\mathbf{1} \mathbf{a}]_{\text {final }}=0.1 \mathrm{M}\right) \text {, blue }} \\
\text { LED irradiation; the temperature of the reaction }\left(25-33^{\circ} \mathrm{C}\right) \text { was controlled } \\
\text { for } 14 \mathrm{~h} \text { using a fan. } \\
\text { b The yield of 3aa was determined by }{ }^{1} \mathrm{H} \text { NMR analysis (internal standard: } \\
\text { nitromethane). }\end{array}$} \\
\hline
\end{tabular}

was not as great as that achieved using pre-formed $\mathbf{6 j}$. The use of $\mathbf{6 e}$ with 2-methoxyethylamine instead of ethanolamine showed a similar acceleration effect (entry 5).

These results suggest that the positive effect of $\mathbf{6} \mathbf{j}$ cannot be simply attributed to the independent contributions of $\mathbf{6 e}$ and ethanolamine. As the amine has a positive effect only in the presence of the boron catalyst, the amine moiety likely promotes the formation of the borate by assisting in the deprotonation of the alcohol substrates.

Interestingly, when the combination of boronic acid $\mathbf{6 a}$ and ethanolamine (Table 5, entry 6 vs 7 ) or 2-methoxyethylamine (entry 6 vs 8 ) was examined, both amines were observed to have a negative effect on the yield. In the presence of the amines, boronic acid $\mathbf{6 a}$ was completely decomposed after the reaction (confirmed by ${ }^{1} \mathrm{H}$ NMR analysis of the crude mixture). The amines may facilitate the oxidative decomposition of boronic acid $\mathbf{6 a},{ }^{10 b, 15}$ leading to a decreased amount of the active bond-weakening catalyst.

We then examined the substrate scope using the optimized conditions (Tables 6 and 7). First, the scope of the alcohol substrates was examined using $\mathbf{1 a}$ as an acceptor (Table 6).
When ethanol (2a) was used, 3aa was obtained in $85 \%$ yield (Table 6 , entry 1 ). The reaction with methanol (2b) produced the expected $\mathrm{C}-\mathrm{H}$ alkylation product $\mathbf{3 a b}$ in a lower yield (35\%), most likely due to the instability of the primary carbon radical generated by the HAT process (entry 2). Despite the expected stability of the carbon radical intermediate, the yield was moderate (50\%) when 2-propanol (3c) was used as the substrate (entry 3 ). The steric hindrance of $2 \mathbf{c}$ may have hampered the formation of the borate with $\mathbf{6 j}$. On the other hand, a substrate bearing a $\beta$-tertiary carbon (2d) afforded the corresponding product 3ad in $81 \%$ yield (entry 4 ). The conditions were also applicable to a long-chain alcohol (2e) and a cyclic alcohol (2f), which furnished the desired products in $76 \%$ (entry 5 ) and $75 \%$ yield (entry 6), respectively. The reaction proceeded in excellent yield even for alcohols with electron-withdrawing groups (83\% and 91\% yield for entries 7 and 8 , respectively). When a mono-protected diol $2 \mathbf{i}$ was used, the $\mathrm{C}-\mathrm{H}$ alkylation proceeded selectively at the $\alpha$-position adjacent to the hydroxy group (entry 9). Subsequently, we examined alcohol substrates bearing multiple $\mathrm{C}-\mathrm{H}$ bonds with similar BDE values.

Despite the presence of cyclic ether $\alpha-\mathrm{C}-\mathrm{H}$ bonds $(\mathbf{2} \mathbf{j})$ or $\mathrm{N}$-heterocyclic $\alpha-\mathrm{C}-\mathrm{H}$ bonds $(\mathbf{2 k})$, which are generally more reactive than the $\alpha-\mathrm{C}-\mathrm{H}$ bonds of alcohols, the $\mathrm{C}-\mathrm{H}$ alkylation selectively occurred at the $\alpha-\mathrm{C}-\mathrm{H}$ bonds of the alcohol to afford the desired products in high yields ( $80 \%$ and $84 \%$, respectively) (Table 6 , entries 10 and 11 ). ${ }^{23}$

Next, the substrate scope of the acceptor was examined using ethanol (2a) or 1-hexanol (2e) as the alcohol substrate (Table 7). Acceptors with a phosphonate, nitrile, amide, ester, or sulfone as the electron-withdrawing group were found to be applicable in this reaction. When esters were used as the acceptors, the corresponding lactones were isolated after acidic work-up (entries 7-9). A range of acrylates and a vinylsulfone produced the desired products in moderate to high yields (entries 1, 3-7 and 10). For acrylamides, a primary amide (1d), secondary amides (1e and $\mathbf{1 f})$, and a tertiary amide (19) afforded the desired products in good yield (entries 3-6). The $\alpha$-substituent of the acceptors was not problematic. When methacrylic acid derivatives or $\alpha$-phenyl methyl acrylate were used, the reaction proceeded smoothly to afford excellent product yields (entries 2,8 and 9 ).

Finally, we attempted the $\mathrm{C}-\mathrm{H}$ alkylation of functionalgroup-enriched molecules (Scheme 2). When the protected amino acid $\mathbf{2 l}$ or homoserine (Hse)-containing dipeptide $2 \mathrm{~m}$ was used, the reaction proceeded in $34 \%$ and $75 \%$ yield, respectively. Of note, $\mathbf{2 l}$ was rather unreactive in the HAT process. The reaction of $\mathbf{2} \mathbf{l}$ in the absence of $\mathbf{6 j}$ or under previously reported conditions did not proceed at all. ${ }^{12}$ These results demonstrate the potential utility of the current hybrid catalyst system for the late-stage modification of peptides. 
Table 6 Substrate Scope of the Alcohols ${ }^{\mathrm{a}}$

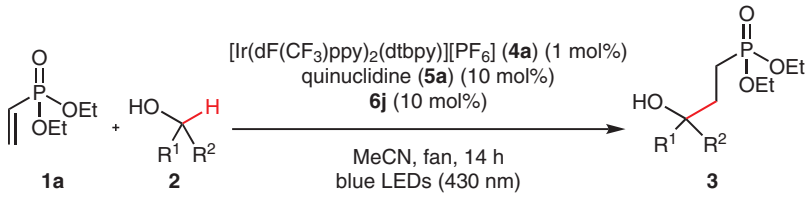

\begin{tabular}{|c|c|c|c|}
\hline Entry & Acceptor & Alcohol & \\
\hline 1 & & & 22 \\
\hline 2 & 0 & HO & $2 b$ \\
\hline 3 & & O. & \\
\hline
\end{tabular}

4<smiles>CCOP(=O)(CC)OCC</smiles>

5<smiles>CCOP1(=O)CCCO1</smiles>

6<smiles>CCOP1(=O)CCCO1</smiles>

7<smiles>CCOP1(=O)C=CCO1</smiles>

8<smiles>CCOP1(=O)CCCO1</smiles>

9<smiles>CCOP(=O)(CC)OCC</smiles><smiles>CC(C)C(C)O</smiles><smiles>CCCCCC(O)O</smiles><smiles>OC1CCCCC1</smiles><smiles>OCCCF</smiles><smiles>OCCCC(F)(F)F</smiles><smiles>[O+2]CCCO</smiles>

85<smiles>CCOP(=O)(CCC([N])O)OCC</smiles><smiles>CCOP(=O)(CC)CCCO</smiles>

50<smiles>CCOP(=O)(CCC(C)(C)O)OCC</smiles>

81<smiles>CCOP(=O)(CCC(O)C(C)C)OCC</smiles>

76

75<smiles>CCOP(=O)(CCC1(O)CCCCC1)OCC</smiles><smiles>CCOP(=O)(CCC(O)CCF)OCC</smiles>

83

91<smiles>CCOP(=O)(CCC(O)CCC(F)(F)F)OCC</smiles><smiles>CCOP(=O)(CCC(O)CCO)OCC</smiles>

Yield (\%)<smiles>CCCC(O)CCP(=O)(OCC)OCC</smiles> 
Table 6 (continued)

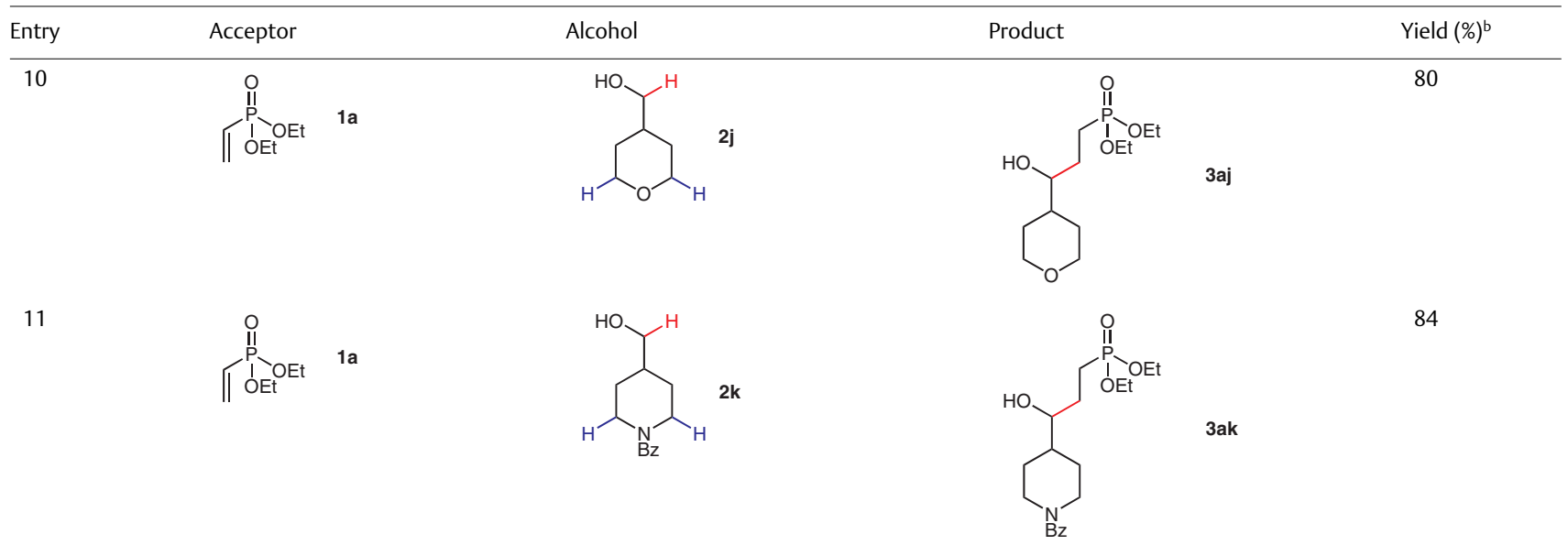

${ }^{a}$ Reaction conditions: acceptor 1a (1 equiv), alcohol 2 (2 equiv), $4 \mathbf{a}(1 \mathrm{~mol} \%), \mathbf{5 a}(10 \mathrm{~mol} \%), \mathbf{6 j}(10 \mathrm{~mol} \%), \mathrm{MeCN}\left([\mathbf{1 a}]_{\text {final }}=0.1 \mathrm{M}\right)$, blue LED irradiation; the temperature of the reaction $\left(25-33^{\circ} \mathrm{C}\right)$ was controlled for $14 \mathrm{~h}$ using a fan.

b Yield of isolated product.

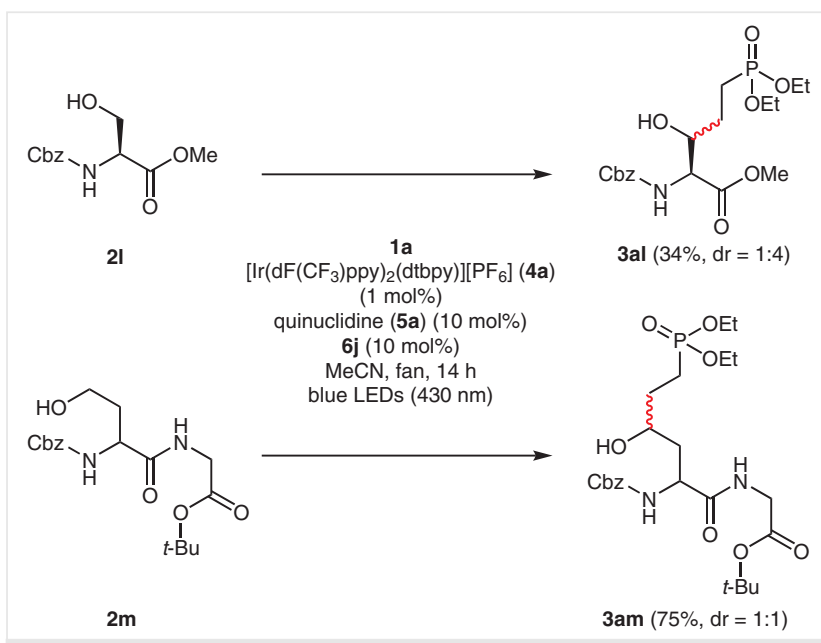

Scheme $2 \mathrm{C}-\mathrm{H}$ alkylation of amino acid derivatives

A plausible catalytic cycle is shown in Scheme 3. First, PC 4a is excited by irradiation with visible light. The photoexcited $\operatorname{Ir}(\mathrm{III})^{*}$ species $\left[E\left(\mathrm{II}^{\mathrm{III} *} / \mathrm{Ir}^{\mathrm{II}}\right)=+1.21 \mathrm{~V} \text { vs SCE}\right]^{9 \mathrm{a}}$ oxidizes HAT catalyst 5a $\left(E_{1 / 2}=+1.10 \mathrm{~V} \text { vs } S C E\right)^{24,25}$ to generate quinuclidinium radical $\mathbf{7}$ and the $\operatorname{Ir}(\mathrm{II})$ species. Anionic borates $\mathbf{8}$ are formed in situ from alcohol substrate $\mathbf{2}$ and borinic acid-ethanolamine complex $\mathbf{6 j}$ to lower the BDE by ca. $5 \mathrm{kcal} / \mathrm{mol}$, which facilitates the subsequent HAT process. The quinuclidinium radical 7 (BDE of $\mathrm{N}^{+}-\mathrm{H}$ bond: 100 $\mathrm{kcal} / \mathrm{mol})^{25}$ homolytically cleaves the $\alpha-\mathrm{C}-\mathrm{H}$ bond of borate $\mathbf{8}$ to generate reactive carbon radical $\mathbf{9}$, and the HAT catalyst is regenerated after releasing a proton. ${ }^{26}$ The thus generated carbon radical $\mathbf{9}$ is trapped by acceptor $\mathbf{1}$ to form stabilized radical 10. The $\operatorname{Ir}(\mathrm{II})$ species $\left[E_{1 / 2}\left(\mathrm{Ir}^{\mathrm{II}} / \mathrm{Ir}^{\mathrm{III}}\right)=-1.37 \mathrm{~V} \text { vs SCE}\right]^{9 \mathrm{a}}$ reduces $\mathbf{1 0}$ to form a carbanionic species. Subsequent protonation and alcohol exchange produce the $\mathrm{C}-\mathrm{H}$ alkylated product 3 , and the catalytic cycle is closed.

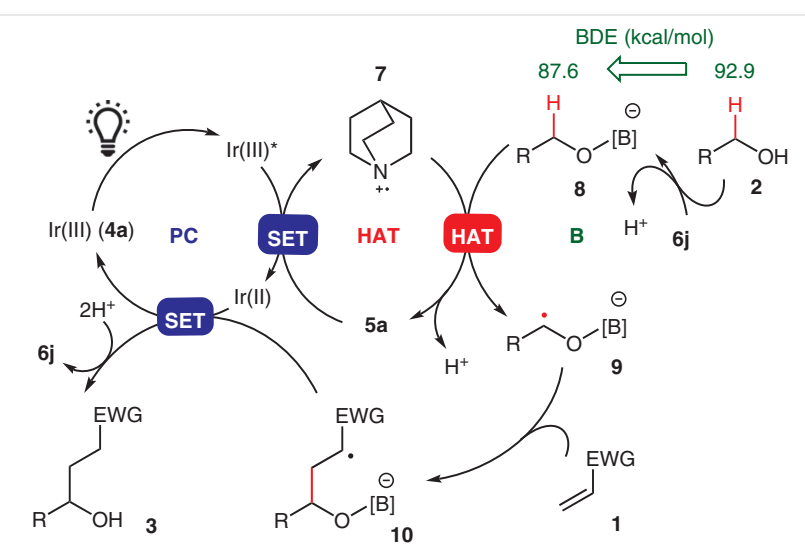

Scheme 3 Proposed catalytic cycle for the $\alpha-\mathrm{C}-\mathrm{H}$ alkylation of alcohols. BDE values calculated by DFT ( $R=M e)$.

In conclusion, we have conducted a DFT-calculationguided screening of bond-weakening borate catalysts and identified electron-deficient borinic acid-ethanolamine complex $\mathbf{6 j}$ as an effective catalyst component for the $\alpha-\mathrm{C}-\mathrm{H}$ alkylation of alcohols. The newly established PC-HATborate hybrid catalyst system enhances the reaction yield and broadens the substrate scope, probably due to the greater bond-weakening effect of the borate relative to that of silicates. Our reaction system can also transform amino acids or peptides, which are inert to silicate- or hydrogenbonding-based bond-weakening systems. 
Table 7 Substrate Scope of the Acceptors ${ }^{\mathrm{a}}$

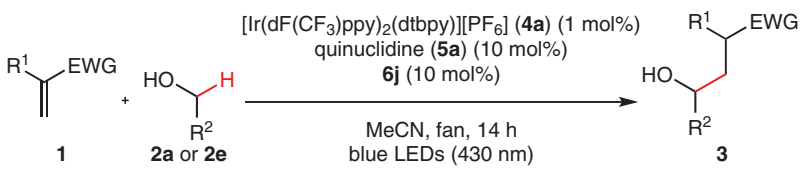

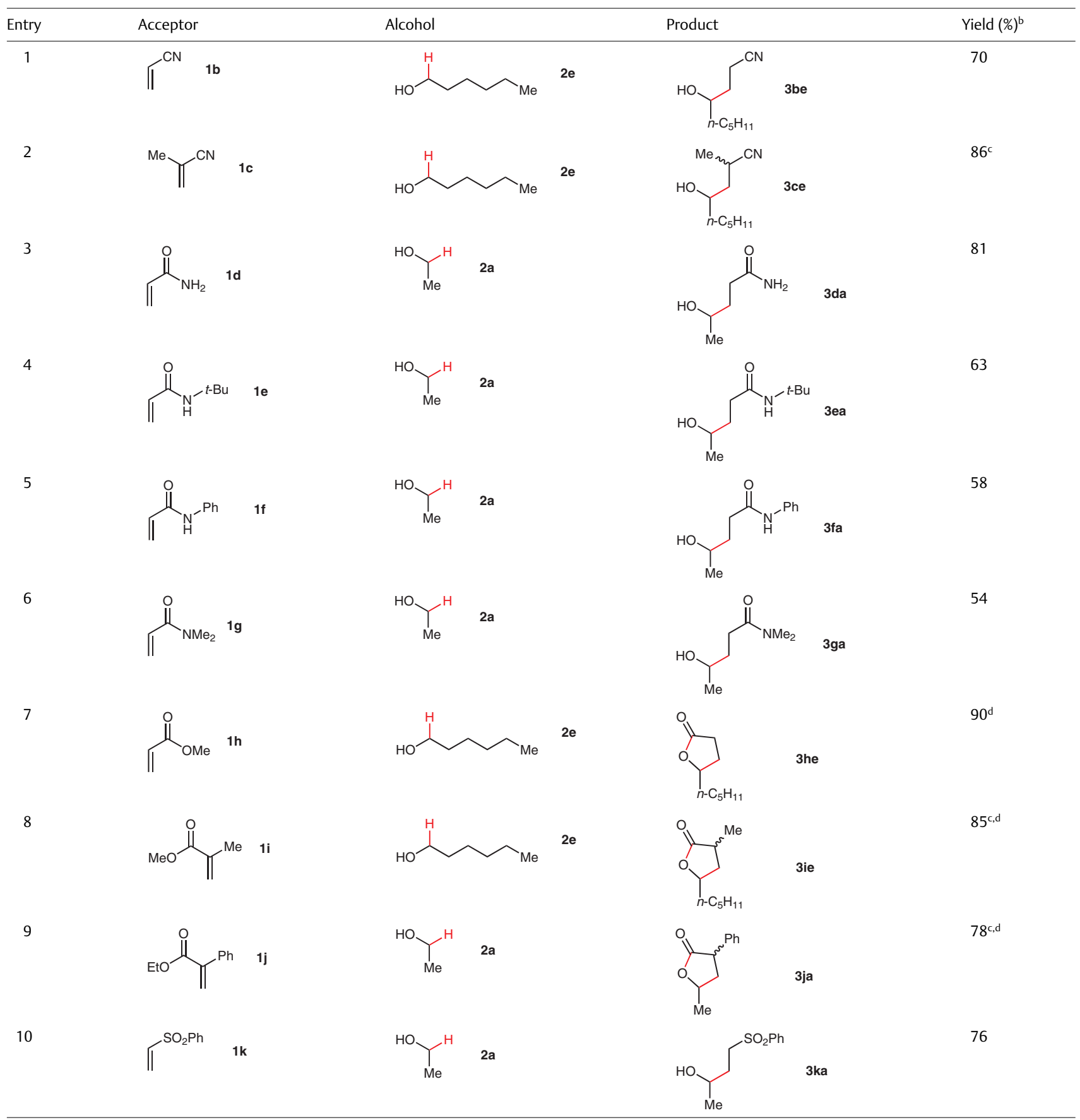

${ }^{a}$ Reaction conditions: acceptor 1 (1 equiv), alcohol 2 (2 equiv), $\mathbf{4 a}(1 \mathrm{~mol} \%), \mathbf{5 a}(10 \mathrm{~mol} \%), \mathbf{6 j}(10 \mathrm{~mol} \%), \mathrm{MeCN}\left([\mathbf{1 a}]_{\text {final }}=0.1 \mathrm{M}\right)$, blue LED irradiation; the temperature of the reaction $\left(25-33^{\circ} \mathrm{C}\right)$ was controlled for $14 \mathrm{~h}$ using a fan.

${ }^{\mathrm{b}}$ Yield of isolated product.

c The dr was 1:1.0 to 1:2.9. See the Supporting Information for details.

${ }^{d}$ After blue LED irradiation, an acidic work-up (Amberlyst ${ }^{\circledR}-15 ; 100 \mathrm{mg}, 3 \mathrm{~h}, 50^{\circ} \mathrm{C}$ ) was conducted. 
All reagents (except for some borinic acids and borinic acid-ethanolamine complexes) and solvents were purchased from common chemical suppliers and used without further purification. Alcohol $\alpha-\mathrm{C}-\mathrm{H}$ alkylation reactions were carried out in dried and degassed $\mathrm{MeCN}$, DMSO, $\mathrm{CH}_{2} \mathrm{Cl}_{2}$, DMF, 1,4-dioxane, benzotrifluoride, or acetone under an argon atmosphere. Analytical TLC was performed on Merck silica gel $60 \mathrm{~F}_{254}$ plates. Flash column chromatography was performed using silica gel (60, spherical, $40-50 \mu \mathrm{m}$; Kanto Chemicals) or a Biotage ${ }^{\circledR}$ Isolera ${ }^{\mathrm{TM}}$ One 3.0 instrument with a pre-packed Biotage ${ }^{\circledR}$ SNAP Ultra column. Infrared (IR) spectra were recorded using a JASCO FT/IR 410 Fourier transform IR spectrophotometer. NMR spectra were recorded using JEOL ECX500 ( ${ }^{1} \mathrm{H}$ NMR: $500 \mathrm{MHz} ;{ }^{13} \mathrm{C}$ NMR: $\left.125 \mathrm{MHz}\right)$, JEOL ECZ500 ( ${ }^{1} \mathrm{H}$ NMR: $500 \mathrm{MHz} ;{ }^{13} \mathrm{C}$ NMR: $\left.125 \mathrm{MHz}\right)$, or JEOL ECS400 $\left({ }^{1} \mathrm{H}\right.$ NMR: $400 \mathrm{MHz} ;{ }^{13} \mathrm{C}$ NMR: $100 \mathrm{MHz}$; ${ }^{11} \mathrm{~B}$ NMR: $126 \mathrm{MHz} ;{ }^{19} \mathrm{~F}$ NMR: $369 \mathrm{MHz}$; ${ }^{31} \mathrm{P}$ NMR: $159 \mathrm{MHz}$ ) spectrometers. Residual traces of the hydrogenated solvents were used as an internal reference for the chemical shifts in the ${ }^{1} \mathrm{H}$ NMR and ${ }^{13} \mathrm{C}$ NMR spectra. In the ${ }^{19} \mathrm{~F}$ NMR spectra, the chemical shifts are reported relative to the external standard hexafluorobenzene $(\delta=-164.90)$. In the ${ }^{11} \mathrm{~B}$ NMR spectra, the chemical shifts are reported relative to the external reference $\mathrm{BF}_{3} \cdot \mathrm{Et}_{2} \mathrm{O}$ $(\delta=0.00)$. In the ${ }^{31} \mathrm{P}$ NMR spectra, the chemical shifts are reported relative to the external reference triphenylphosphine $(\delta=-6.00)$. Coupling constants $(J)$ are reported in hertz $(\mathrm{Hz})$, while multiplicities are described using standard abbreviations. ESI-mass spectra were measured using a Bruker micrOTOF spectrometer or a JEOL JMS-T100LC AccuTOF spectrometer for HRMS. DART-mass spectra were measured using a JEOL JMS-T100LC AccuTOF spectrometer for HRMS. ESI-mass spectra were measured using a JEOL JMS-T100LC AccuTOF spectrometer for LRMS. Gel permeation chromatography (GPC) was performed on a recycling preparative HPLC LC9210 NEXT system (Japan Analytical Industry Co., Ltd.). The synthesis of boron sources $\mathbf{6 e}$ and $\mathbf{6 j}$ and substrates $\mathbf{1 j} \mathbf{j}, \mathbf{2} \mathbf{i}$, and $\mathbf{2 k}$ is described in the Supporting Information.

\section{Photocatalytic C-H Alkylation of Alcohols; General Procedure}

[ $\left.\operatorname{Ir}\left(\mathrm{dF}\left(\mathrm{CF}_{3}\right) \mathrm{ppy}\right)_{2}(\mathrm{dtbpy})\right]\left[\mathrm{PF}_{6}\right](\mathbf{4 a})(1.1 \mathrm{mg}, 1.0 \mu \mathrm{mol}, 1 \mathrm{~mol} \%)$, quinuclidine $(\mathbf{5 a})(1.1 \mathrm{mg}, 0.010 \mathrm{mmol}, 10 \mathrm{~mol} \%$ ), and 2,2-bis[4-(trifluoromethyl)phenyl)-1,3,2 $\lambda^{4}$-oxazaborolidine (6j) (3.6 mg, $0.010 \mathrm{mmol}, 10$ mol\%) were added to a dried screw-cap vial. Degassed MeCN $(1.0 \mathrm{~mL}$, $\left.[1]_{\text {final }}=0.1 \mathrm{M}\right)$, alcohol $2(0.20 \mathrm{mmol}, 2.0$ equiv $)$ and Michael acceptor $1(0.10 \mathrm{mmol}, 1.0$ equiv) were added to the vial under an argon atmosphere or in a glove box, before the vial was sealed with the screw cap. The vial was removed from the glove box and then placed near the $430 \mathrm{~nm}$ light source [Valore VBP-L24-C2 with a 38 W LED lamp; VBL-SE150-BBB $(430)]$. The temperature $\left(25-33^{\circ} \mathrm{C}\right)$ was controlled using a strong fan, and the vial was irradiated for $14 \mathrm{~h}$ with the blue LEDs under constant stirring. After evaporation of all volatiles, the residue was purified by flash column chromatography (GPC was used for the purification of 3aj and 3ie) to afford the targeted $\mathrm{C}-\mathrm{H}$ alkylation products 3 .

\section{Diethyl (3-Hydroxybutyl)phosphonate (3aa)}

Pale-yellow oil; yield: $17.9 \mathrm{mg}$ (85\%); $R_{f}=0.29\left(\mathrm{CH}_{2} \mathrm{Cl}_{2} / \mathrm{MeOH}, 20: 1\right)$. IR $\left(\mathrm{CH}_{2} \mathrm{Cl}_{2}\right): 3397,2978,1239,1029,963,789 \mathrm{~cm}^{-1}$.

${ }^{1} \mathrm{H} \mathrm{NMR}\left(400 \mathrm{MHz}, \mathrm{CDCl}_{3}\right): \delta=4.17-4.03(\mathrm{~m}, 4 \mathrm{H}), 3.90-3.82(\mathrm{~m}, 1 \mathrm{H})$, 2.18 (br s, 1 H), 1.96-1.61 (m, 4 H), 1.32 (t, $J=7.3 \mathrm{~Hz}, 6 \mathrm{H}), 1.21$ (d, $J=$ $6.4 \mathrm{~Hz}, 3 \mathrm{H})$.

${ }^{13} \mathrm{C}$ NMR $\left(125 \mathrm{MHz}, \mathrm{CDCl}_{3}\right): \delta=67.4(\mathrm{~d}, J=15.5 \mathrm{~Hz}), 61.8(\mathrm{~d}, J=4.8$ $\mathrm{Hz}), 61.7(\mathrm{~d}, J=6.0 \mathrm{~Hz}), 31.7(\mathrm{~d}, J=4.8 \mathrm{~Hz}), 23.2,22.0(\mathrm{~d}, J=140.7 \mathrm{~Hz})$, $16.5(\mathrm{~d}, J=6.0 \mathrm{~Hz})$.
${ }^{31} \mathrm{P} \operatorname{NMR}\left(159 \mathrm{MHz}, \mathrm{CDCl}_{3}\right): \delta=32.8$.

HRMS (ESI): $m / z[\mathrm{M}+\mathrm{Na}]^{+}$calcd for $\mathrm{C}_{8} \mathrm{H}_{19} \mathrm{NaO}_{4} \mathrm{P}: 233.0913$; found: 233.0917.

\section{Diethyl (3-Hydroxypropyl)phosphonate (3ab)}

Colorless oil; yield: $6.9 \mathrm{mg}$ (35\%); $R_{f}=0.18\left(\mathrm{CH}_{2} \mathrm{Cl}_{2} / \mathrm{MeOH}, 20: 1\right)$.

IR $\left(\mathrm{CH}_{2} \mathrm{Cl}_{2}\right): 3397,2983,2933,1229,1027,962,750 \mathrm{~cm}^{-1}$.

${ }^{1} \mathrm{H}$ NMR $\left(400 \mathrm{MHz}, \mathrm{CDCl}_{3}\right): \delta=4.18-4.04(\mathrm{~m}, 4 \mathrm{H}), 3.71(\mathrm{t}, J=5.7 \mathrm{~Hz}, 2$ $\mathrm{H}$ ), 2.23 (br s, $1 \mathrm{H}$; overlaps with the signal for water), 1.93-1.80 ( $\mathrm{m}, 4$ $\mathrm{H}), 1.33(\mathrm{t}, J=7.3 \mathrm{~Hz}, 6 \mathrm{H})$.

${ }^{13} \mathrm{C} \operatorname{NMR}\left(100 \mathrm{MHz}, \mathrm{CDCl}_{3}\right): \delta=62.7(\mathrm{~d}, J=13.4 \mathrm{~Hz}), 61.9(\mathrm{~d}, J=6.7 \mathrm{~Hz})$, $25.8(\mathrm{~d}, J=4.8 \mathrm{~Hz}), 22.8(\mathrm{~d}, J=144.0 \mathrm{~Hz}), 16.6(\mathrm{~d}, J=5.7 \mathrm{~Hz})$.

${ }^{31} \mathrm{P}$ NMR $\left(159 \mathrm{MHz}, \mathrm{CDCl}_{3}\right): \delta=32.7$.

HRMS (ESI): $m / z[\mathrm{M}+\mathrm{Na}]^{+}$calcd for $\mathrm{C}_{7} \mathrm{H}_{17} \mathrm{NaO}_{4} \mathrm{P}: 219.0757$; found: 219.0767.

\section{Diethyl (3-Hydroxy-3-methylbutyl)phosphonate (3ac)}

Pale-yellow oil; yield: $11.3 \mathrm{mg}$ (50\%); $R_{f}=0.38\left(\mathrm{CH}_{2} \mathrm{Cl}_{2} / \mathrm{MeOH}, 20: 1\right)$.

IR $\left(\mathrm{CH}_{2} \mathrm{Cl}_{2}\right)$ : 3404, 2973, 2930, 1223, 1027, $961 \mathrm{~cm}^{-1}$.

${ }^{1} \mathrm{H}$ NMR (400 MHz, CDCl $): \delta=4.17-4.03(\mathrm{~m}, 4 \mathrm{H}), 1.90-1.72(\mathrm{~m}, 5 \mathrm{H}$; overlaps with the signal for water), $1.33(\mathrm{t}, J=7.3 \mathrm{~Hz}, 6 \mathrm{H}), 1.23(\mathrm{~s}, 6$ $\mathrm{H})$.

${ }^{13} \mathrm{C} \mathrm{NMR}\left(125 \mathrm{MHz}, \mathrm{CDCl}_{3}\right): \delta=69.8(\mathrm{~d}, J=15.5 \mathrm{~Hz}), 61.7(\mathrm{~d}, J=6.0 \mathrm{~Hz})$, $35.8(\mathrm{~d}, J=4.8 \mathrm{~Hz}), 28.9,20.6$ (d, $J=140.7 \mathrm{~Hz}), 16.5$ (d, $J=6.0 \mathrm{~Hz})$.

${ }^{31} \mathrm{P}$ NMR (159 MHz, $\left.\mathrm{CDCl}_{3}\right): \delta=33.1$.

HRMS (ESI): $m / z[\mathrm{M}+\mathrm{Na}]^{+}$calcd for $\mathrm{C}_{9} \mathrm{H}_{21} \mathrm{NaO}_{4} \mathrm{P}: 247.1070$; found: 247.1067.

\section{Diethyl (3-Hydroxy-4-methylpentyl)phosphonate (3ad)}

Colorless oil; yield: $19.3 \mathrm{mg}$ (81\%); $R_{f}=0.26\left(\mathrm{CH}_{2} \mathrm{Cl}_{2} / \mathrm{MeOH}, 20: 1\right)$.

IR $\left(\mathrm{CH}_{2} \mathrm{Cl}_{2}\right): 3397,2959,2873,1234,1029,962,749 \mathrm{~cm}^{-1}$.

$\left.{ }^{1} \mathrm{H} \mathrm{NMR} \mathrm{(400} \mathrm{MHz,} \mathrm{CDCl}_{3}\right): \delta=4.17-4.03(\mathrm{~m}, 4 \mathrm{H}), 3.92-3.35(\mathrm{~m}, 1 \mathrm{H})$, 2.17 (br s, $1 \mathrm{H}), 2.01-1.89(\mathrm{~m}, 1 \mathrm{H}), 1.86-1.74(\mathrm{~m}, 2 \mathrm{H}), 1.70-1.57$ (m, $2 \mathrm{H}), 1.32(\mathrm{t}, J=7.1 \mathrm{~Hz}, 6 \mathrm{H}), 0.93(\mathrm{~d}, J=6.0 \mathrm{~Hz}, 3 \mathrm{H}), 0.91(\mathrm{~d}, J=6.4 \mathrm{~Hz}$, $3 \mathrm{H})$.

${ }^{13} \mathrm{C}$ NMR $\left(125 \mathrm{MHz}, \mathrm{CDCl}_{3}\right): \delta=76.6(\mathrm{~d}, J=13.1 \mathrm{~Hz}), 61.8(\mathrm{~d}, J=3.6$ $\mathrm{Hz}), 61.8(\mathrm{~d}, J=3.6 \mathrm{~Hz}), 33.8,27.1(\mathrm{~d}, J=4.8 \mathrm{~Hz}), 22.5(\mathrm{~d}, J=140.7 \mathrm{~Hz})$, $18.8,17.7,16.6(\mathrm{~d}, J=6.0 \mathrm{~Hz})$.

${ }^{31} \mathrm{P} \operatorname{NMR}\left(159 \mathrm{MHz}, \mathrm{CDCl}_{3}\right): \delta=33.0$.

HRMS (ESI): $m / z[\mathrm{M}+\mathrm{Na}]^{+}$calcd for $\mathrm{C}_{10} \mathrm{H}_{23} \mathrm{NaO}_{4} \mathrm{P}: 261.1226$; found: 261.1223.

\section{Diethyl (3-Hydroxyoctyl)phosphonate (3ae)}

Pale-yellow oil; yield: $20.2 \mathrm{mg}$ (76\%); $R_{f}=0.21\left(\mathrm{CH}_{2} \mathrm{Cl}_{2} / \mathrm{MeOH}, 20: 1\right)$. IR $\left(\mathrm{CH}_{2} \mathrm{Cl}_{2}\right)$ : 3399, 2930, 2859, 1228, 1031, $962 \mathrm{~cm}^{-1}$.

${ }^{1} \mathrm{H}$ NMR $\left(500 \mathrm{MHz}, \mathrm{CDCl}_{3}\right): \delta=4.16-4.03(\mathrm{~m}, 4 \mathrm{H}), 3.65-3.61(\mathrm{~m}, 1 \mathrm{H})$, 2.18 (br s, $1 \mathrm{H}), 1.96-1.76(\mathrm{~m}, 3 \mathrm{H}), 1.69-1.59(\mathrm{~m}, 1 \mathrm{H}), 1.48-1.20(\mathrm{~m}$, $8 \mathrm{H}), 1.32(\mathrm{t}, J=7.2 \mathrm{~Hz}, 6 \mathrm{H}), 0.88(\mathrm{t}, J=6.9 \mathrm{~Hz}, 3 \mathrm{H})$.

${ }^{13} \mathrm{C} \mathrm{NMR}\left(125 \mathrm{MHz}, \mathrm{CDCl}_{3}\right): \delta=71.6(\mathrm{~d}, J=13.1 \mathrm{~Hz}), 61.8(\mathrm{~d}, J=6.0 \mathrm{~Hz})$, $61.8(\mathrm{~d}, J=6.0 \mathrm{~Hz}), 37.4,32.0,30.2(\mathrm{~d}, J=4.8 \mathrm{~Hz}), 25.5,22.2(\mathrm{~d}, J=$ $139.5 \mathrm{~Hz}), 16.6(\mathrm{~d}, J=6.0 \mathrm{~Hz}), 14.2$.

${ }^{31} \mathrm{P}$ NMR $\left(159 \mathrm{MHz}, \mathrm{CDCl}_{3}\right): \delta=32.9$.

HRMS (ESI): $m / z[\mathrm{M}+\mathrm{Na}]^{+}$calcd for $\mathrm{C}_{12} \mathrm{H}_{27} \mathrm{NaO}_{4} \mathrm{P}: 289.1539$; found: 289.1539 . 


\section{Diethyl [2-(1-Hydroxycyclohexyl)ethyl]phosphonate (3af)}

Pale-yellow oil; yield: $19.8 \mathrm{mg}(75 \%) ; R_{f}=0.26\left(\mathrm{CH}_{2} \mathrm{Cl}_{2} / \mathrm{MeOH}, 20: 1\right)$. IR $\left(\mathrm{CH}_{2} \mathrm{Cl}_{2}\right): 3399,2981,2931,2857,1219,1030,964 \mathrm{~cm}^{-1}$.

${ }^{1} \mathrm{H}$ NMR (500 MHz, $\left.\mathrm{CDCl}_{3}\right): \delta=4.14-4.03(\mathrm{~m}, 4 \mathrm{H}), 1.94$ (br s, $1 \mathrm{H}$ ), 1.87-1.78 (m, 2 H), 1.76-1.69 (m, 2 H), 1.62-1.42 (m, 7 H), 1.39-1.22 $(\mathrm{m}, 3 \mathrm{H}), 1.31(\mathrm{t}, J=7.2 \mathrm{~Hz}, 6 \mathrm{H})$.

${ }^{13} \mathrm{C} \mathrm{NMR}\left(125 \mathrm{MHz}, \mathrm{CDCl}_{3}\right): \delta=70.6(\mathrm{~d}, J=15.5 \mathrm{~Hz}), 61.7(\mathrm{~d}, J=6.0 \mathrm{~Hz})$, $37.2,34.6,25.9,22.2,19.5(\mathrm{~d}, J=141.9 \mathrm{~Hz}), 16.6(\mathrm{~d}, J=6.0 \mathrm{~Hz})$.

${ }^{31} \mathrm{P}$ NMR $\left(159 \mathrm{MHz}, \mathrm{CDCl}_{3}\right): \delta=33.6$.

HRMS (ESI): $m / z[\mathrm{M}+\mathrm{Na}]^{+}$calcd for $\mathrm{C}_{12} \mathrm{H}_{25} \mathrm{NaO}_{4} \mathrm{P}: 287.1383$; found: 287.1389.

\section{Diethyl (5-Fluoro-3-hydroxypentyl)phosphonate (3ag)}

Pale-yellow oil; yield: $20.1 \mathrm{mg}$ (83\%); $R_{\mathrm{f}}=0.18\left(\mathrm{CH}_{2} \mathrm{Cl}_{2} / \mathrm{MeOH}, 20: 1\right)$. IR $\left(\mathrm{CH}_{2} \mathrm{Cl}_{2}\right): 3384,2982,2910,1232,1028,965 \mathrm{~cm}^{-1}$.

${ }^{1} \mathrm{H}$ NMR $\left(400 \mathrm{MHz}, \mathrm{CDCl}_{3}\right): \delta=4.74-4.49(\mathrm{~m}, 2 \mathrm{H}), 4.17-4.02(\mathrm{~m}, 4 \mathrm{H})$, $3.90-3.84(\mathrm{~m}, 1 \mathrm{H}), 2.66$ (br s, $1 \mathrm{H}), 1.98-1.65(\mathrm{~m}, 6 \mathrm{H}), 1.32(\mathrm{t}, J=7.3$ $\mathrm{Hz}, 6 \mathrm{H})$.

${ }^{13} \mathrm{C} \mathrm{NMR}\left(125 \mathrm{MHz}, \mathrm{CDCl}_{3}\right): \delta=81.7\left(\mathrm{~d}, J_{\mathrm{C}-\mathrm{F}}=162.2 \mathrm{~Hz}\right), 68.1\left(\mathrm{dd}, J_{\mathrm{C}-\mathrm{P}}=\right.$ $12.5 \mathrm{~Hz}$ and $\left.J_{\mathrm{C}-\mathrm{F}}=4.8 \mathrm{~Hz}\right), 62.0\left(\mathrm{~d}, J_{\mathrm{C}-\mathrm{P}}=6.0 \mathrm{~Hz}\right), 61.9\left(\mathrm{~d}, J_{\mathrm{C}-\mathrm{P}}=6.0 \mathrm{~Hz}\right)$, $37.8\left(\mathrm{~d}, J_{\mathrm{C}-\mathrm{F}}=19.1 \mathrm{~Hz}\right), 30.5\left(\mathrm{~d}, J_{\mathrm{C}-\mathrm{P}}=4.8 \mathrm{~Hz}\right), 22.2\left(\mathrm{~d}, J_{\mathrm{C}-\mathrm{P}}=140.7 \mathrm{~Hz}\right)$, $16.6\left(\mathrm{~d}, J_{\mathrm{C}-\mathrm{P}}=6.0 \mathrm{~Hz}\right)$.

${ }^{19} \mathrm{~F} \mathrm{NMR}\left(369 \mathrm{MHz}, \mathrm{CDCl}_{3}\right): \delta=-220.0$ to $-220.3(\mathrm{~m})$.

${ }^{31} \mathrm{P}$ NMR $\left(159 \mathrm{MHz}, \mathrm{CDCl}_{3}\right): \delta=32.7$.

HRMS (ESI): $m / z[\mathrm{M}+\mathrm{Na}]^{+}$calcd for $\mathrm{C}_{9} \mathrm{H}_{20} \mathrm{FNaO}_{4} \mathrm{P}: 265.0975$; found: 265.0983.

\section{Diethyl (6,6,6-Trifluoro-3-hydroxyhexyl)phosphonate (3ah)}

Pale-yellow oil; yield: $26.6 \mathrm{mg}(91 \%) ; R_{f}=0.47\left(\mathrm{CH}_{2} \mathrm{Cl}_{2} / \mathrm{MeOH}, 10: 1\right)$. IR $\left(\mathrm{CH}_{2} \mathrm{Cl}_{2}\right): 3376,2985,2935,1253,1135,1030,964 \mathrm{~cm}^{-1}$.

${ }^{1} \mathrm{H}$ NMR ( $\left.400 \mathrm{MHz}, \mathrm{CDCl}_{3}\right): \delta=4.18-4.02(\mathrm{~m}, 4 \mathrm{H}), 3.72-3.67(\mathrm{~m}, 1 \mathrm{H})$, 2.74 (br s, $1 \mathrm{H}), 2.43-2.27(\mathrm{~m}, 1 \mathrm{H}), 2.23-2.06(\mathrm{~m}, 1 \mathrm{H}), 1.92-1.60(\mathrm{~m}$, $6 \mathrm{H}), 1.32$ (t, $J=7.3 \mathrm{~Hz}, 6 \mathrm{H})$.

${ }^{13} \mathrm{C} \mathrm{NMR}\left(125 \mathrm{MHz}, \mathrm{CDCl}_{3}\right): \delta=127.5\left(\mathrm{q}, J_{\mathrm{C}-\mathrm{F}}=274.2 \mathrm{~Hz}\right), 69.9\left(\mathrm{~d}, J_{\mathrm{C}-\mathrm{P}}=\right.$ $10.7 \mathrm{~Hz}), 62.1\left(\mathrm{~d}, J_{\mathrm{C}-\mathrm{P}}=6.0 \mathrm{~Hz}\right), 62.0\left(\mathrm{~d}, J_{\mathrm{C}-\mathrm{P}}=6.0 \mathrm{~Hz}\right), 30.5\left(\mathrm{q}, J_{\mathrm{C}-\mathrm{F}}=28.6\right.$ $\mathrm{Hz}), 30.5\left(\mathrm{~d}, J_{\mathrm{C}-\mathrm{P}}=4.8 \mathrm{~Hz}\right), 29.6\left(\mathrm{q}, J_{\mathrm{C}-\mathrm{F}}=2.4 \mathrm{~Hz}\right), 22.3\left(\mathrm{~d}, J_{\mathrm{C}-\mathrm{P}}=140.7\right.$ $\mathrm{Hz}), 16.6\left(\mathrm{~d}, J_{\mathrm{C}-\mathrm{p}}=6.0 \mathrm{~Hz}\right)$.

${ }^{19} \mathrm{~F} \mathrm{NMR}\left(369 \mathrm{MHz}, \mathrm{CDCl}_{3}\right): \delta=-65.9(\mathrm{t}, J=19.9 \mathrm{~Hz})$.

${ }^{31} \mathrm{P}$ NMR $\left(159 \mathrm{MHz}, \mathrm{CDCl}_{3}\right): \delta=32.6$.

HRMS (ESI): $m / z$ [M + Na] $]^{+}$calcd for $\mathrm{C}_{10} \mathrm{H}_{20} \mathrm{~F}_{3} \mathrm{NaO}_{4} \mathrm{P}: 315.0944$; found: 315.0941 .

\section{5-(Diethoxyphosphoryl)-3-hydroxypentyl Benzoate (3ai)}

Pale-yellow oil; yield: $20.0 \mathrm{mg}(58 \%) ; R_{f}=0.21\left(\mathrm{CH}_{2} \mathrm{Cl}_{2} / \mathrm{MeOH}, 20: 1\right)$. IR $\left(\mathrm{CH}_{2} \mathrm{Cl}_{2}\right): 3378,2981,2932,1717,1277,1235,1117,1027,963,714$ $\mathrm{cm}^{-1}$.

${ }^{1} \mathrm{H}$ NMR $\left(400 \mathrm{MHz}, \mathrm{CDCl}_{3}\right): \delta=8.04-8.02(\mathrm{~m}, 2 \mathrm{H}), 7.59-7.55(\mathrm{~m}, 1 \mathrm{H})$, $7.44(\mathrm{dd}, J=8.0,8.0 \mathrm{~Hz}, 2 \mathrm{H}), 4.65-4.59(\mathrm{~m}, 1 \mathrm{H}), 4.43-4.38(\mathrm{~m}, 1 \mathrm{H})$, 4.15-4.04 (m, 4 H), 3.84-3.80 (m, $1 \mathrm{H}), 3.14$ (br s, $1 \mathrm{H}), 1.98-1.68$ (m, $6 \mathrm{H}), 1.31(\mathrm{t}, J=7.1 \mathrm{~Hz}, 6 \mathrm{H})$.

${ }^{13} \mathrm{C}$ NMR $\left(125 \mathrm{MHz}, \mathrm{CDCl}_{3}\right): \delta=167.1,133.2,130.2,129.7,128.5,68.2$ $(\mathrm{d}, J=13.1 \mathrm{~Hz}), 62.1,61.9(\mathrm{~d}, J=6.0 \mathrm{~Hz}), 61.8(\mathrm{~d}, J=6.0 \mathrm{~Hz}), 36.6,30.3$ $(\mathrm{d}, J=4.8 \mathrm{~Hz}), 22.3(\mathrm{~d}, J=140.7 \mathrm{~Hz}), 16.6(\mathrm{~d}, J=6.0 \mathrm{~Hz})$.
${ }^{31} \mathrm{P} \operatorname{NMR}\left(159 \mathrm{MHz}, \mathrm{CDCl}_{3}\right): \delta=32.5$.

HRMS (ESI): $m / z[\mathrm{M}+\mathrm{Na}]^{+}$calcd for $\mathrm{C}_{16} \mathrm{H}_{25} \mathrm{NaO}_{6} \mathrm{P}: 367.1281$; found: 367.1265 .

Diethyl [3-Hydroxy-3-(tetrahydro-2H-pyran-4-yl)propyl]phosphonate (3aj)

Pale-yellow oil; yield: $22.3 \mathrm{mg}(80 \%) ; R_{f}=0.15\left(\mathrm{CH}_{2} \mathrm{Cl}_{2} / \mathrm{MeOH}, 20: 1\right)$. IR $\left(\mathrm{CH}_{2} \mathrm{Cl}_{2}\right)$ : 3398, 2949, 2845, 1233, 1029, $962 \mathrm{~cm}^{-1}$.

${ }^{1} \mathrm{H} \mathrm{NMR}\left(500 \mathrm{MHz}, \mathrm{CDCl}_{3}\right): \delta=4.15-4.03(\mathrm{~m}, 4 \mathrm{H}), 3.99$ (ddd, $J=11.6$, 11.6, 3.6 Hz, $2 \mathrm{H}$ ), 3.40-3.33 (m, $3 \mathrm{H}$ ), 2.40 (br s, $1 \mathrm{H}$; overlaps with the signal for water), $1.98-1.35(\mathrm{~m}, 9 \mathrm{H}), 1.32(\mathrm{t}, J=7.2 \mathrm{~Hz}, 6 \mathrm{H})$.

${ }^{13} \mathrm{C}$ NMR $\left(125 \mathrm{MHz}, \mathrm{CDCl}_{3}\right): \delta=75.1(\mathrm{~d}, J=11.9 \mathrm{~Hz}), 68.1,67.9,61.9(\mathrm{~d}$, $J=3.6 \mathrm{~Hz}), 61.8(\mathrm{~d}, J=3.6 \mathrm{~Hz}), 41.1,29.2,28.7,27.0(\mathrm{~d}, J=4.8 \mathrm{~Hz}), 22.2$ $(\mathrm{d}, J=140.7 \mathrm{~Hz}), 16.6(\mathrm{~d}, J=6.0 \mathrm{~Hz})$.

${ }^{31} \mathrm{P}$ NMR $\left(159 \mathrm{MHz}, \mathrm{CDCl}_{3}\right): \delta=32.9$.

HRMS (ESI): $m / z[\mathrm{M}+\mathrm{Na}]^{+}$calcd for $\mathrm{C}_{12} \mathrm{H}_{25} \mathrm{NaO}_{5} \mathrm{P}: 303.1332$; found: 303.1331.

\section{Diethyl [3-(1-Benzoylpiperidin-4-yl)-3-hydroxypropyl]phospho-} nate (3ak)

Pale-yellow oil; yield: $32.1 \mathrm{mg}$ (84\%); $R_{f}=0.23\left(\mathrm{CH}_{2} \mathrm{Cl}_{2} / \mathrm{MeOH}, 20: 1\right)$. IR $\left(\mathrm{CH}_{2} \mathrm{Cl}_{2}\right): 3390,2982,2932,2861,1629,1444,1241,1029,964,710$ $\mathrm{cm}^{-1}$.

${ }^{1} \mathrm{H}$ NMR $\left(500 \mathrm{MHz}, \mathrm{CDCl}_{3}\right): \delta=7.37$ (br m, $5 \mathrm{H}$ ), 4.75 (br m, $\left.1 \mathrm{H}\right), 4.14-$ 4.02 (m, $4 \mathrm{H}$ ), 3.77 (br m, $1 \mathrm{H}$ ), 3.43-3.41 (m, $1 \mathrm{H}), 2.92-2.70$ (br m, 3 $\mathrm{H}), 1.96-1.57(\mathrm{~m}, 7 \mathrm{H}), 1.43-1.18(\mathrm{~m}, 2 \mathrm{H}), 1.31(\mathrm{t}, J=6.9 \mathrm{~Hz}, 6 \mathrm{H})$.

${ }^{13} \mathrm{C}$ NMR $\left(125 \mathrm{MHz}, \mathrm{CDCl}_{3}\right): \delta=170.4,136.3,129.6,128.5,126.9,74.5$ $(\mathrm{d}, J=10.7 \mathrm{~Hz}), 61.9(\mathrm{~d}, J=6.0 \mathrm{~Hz}), 61.9(\mathrm{~d}, J=4.8 \mathrm{~Hz}), 48.0,42.4,42.3$, 29.0, 28.3, $27.2(\mathrm{~d}, J=3.6 \mathrm{~Hz}), 22.3(\mathrm{~d}, J=140.7 \mathrm{~Hz}), 16.6(\mathrm{~d}, J=6.0 \mathrm{~Hz})$. ${ }^{31} \mathrm{P} \operatorname{NMR}\left(159 \mathrm{MHz}, \mathrm{CDCl}_{3}\right): \delta=32.8$.

HRMS (ESI): $m / z$ [M $+\mathrm{Na}]^{+}$calcd for $\mathrm{C}_{19} \mathrm{H}_{30} \mathrm{NNaO}_{5} \mathrm{P}: 406.1754$; found: 406.1740 .

\section{4-Hydroxynonanenitrile (3be)}

Colorless oil; yield: $10.9 \mathrm{mg}$ (70\%); $R_{f}=0.14$ ( $n$-hexane/EtOAc, 4:1).

IR $\left(\mathrm{CH}_{2} \mathrm{Cl}_{2}\right)$ : 3432, 2930, 2859, 2247, 1458, 1056, $655 \mathrm{~cm}^{-1}$.

${ }^{1} \mathrm{H}$ NMR $\left(400 \mathrm{MHz}, \mathrm{CDCl}_{3}\right): \delta=3.75-3.69(\mathrm{~m}, 1 \mathrm{H}), 2.53-2.49(\mathrm{~m}, 2 \mathrm{H})$, $1.88-1.80(\mathrm{~m}, 1 \mathrm{H}), 1.73-1.64(\mathrm{~m}, 1 \mathrm{H}), 1.54$ (br s, $1 \mathrm{H}), 1.51-1.26(\mathrm{~m}$, $8 \mathrm{H}), 0.89(\mathrm{t}, J=6.9 \mathrm{~Hz}, 3 \mathrm{H})$.

${ }^{13} \mathrm{C}$ NMR $\left(100 \mathrm{MHz}, \mathrm{CDCl}_{3}\right): \delta=120.1,70.2,37.6,32.6,31.8,25.3,22.7$, $14.1,13.9$.

HRMS (ESI): $m / z$ [M $+\mathrm{Na}]^{+}$calcd for $\mathrm{C}_{9} \mathrm{H}_{17} \mathrm{NNaO}$ : 178.1202 ; found: 178.1202 .

\section{4-Hydroxy-2-methylnonanenitrile (3ce)}

Obtained as inseparable diastereomers $(\mathrm{dr}=1: 1.3)$.

Colorless oil; yield: $14.5 \mathrm{mg}$ (86\%); $R_{f}=0.23$ ( $n$-hexane/EtOAc, 4:1).

IR $\left(\mathrm{CH}_{2} \mathrm{Cl}_{2}\right): 3440,2930,2859,2241,1458,1095,750 \mathrm{~cm}^{-1}$.

${ }^{1} \mathrm{H} \mathrm{NMR}\left(400 \mathrm{MHz}, \mathrm{CDCl}_{3}\right): \delta$ (major diastereomer) $=3.75-3.69(\mathrm{~m}, 1$ H), 2.90-2.81 (m, $1 \mathrm{H}), 1.87-1.80(\mathrm{~m}, 1 \mathrm{H}), 1.74-1.24(\mathrm{~m}, 10 \mathrm{H}), 1.34$ $(\mathrm{d}, J=7.3 \mathrm{~Hz}, 3 \mathrm{H}), 0.89(\mathrm{t}, J=6.9 \mathrm{~Hz}, 3 \mathrm{H})$.

${ }^{1} \mathrm{H}$ NMR (400 MHz, $\left.\mathrm{CDCl}_{3}\right): \delta$ (minor diastereomer) $=3.88-3.82(\mathrm{~m}, 1$ $\mathrm{H}), 3.03-2.94(\mathrm{~m}, 1 \mathrm{H}), 1.74-1.24(\mathrm{~m}, 11 \mathrm{H}), 1.34(\mathrm{~d}, J=7.3 \mathrm{~Hz}, 3 \mathrm{H})$, $0.89(\mathrm{t}, J=6.9 \mathrm{~Hz}, 3 \mathrm{H})$. 
${ }^{13} \mathrm{C}$ NMR $\left(125 \mathrm{MHz}, \mathrm{CDCl}_{3}\right): \delta=123.7,123.1,69.6,69.0,41.7,41.1$, $38.1,37.8,31.8,31.8,25.2,22.7,22.7,21.9,18.6,17.7,14.1$ (three methylene carbon signals overlap with those of the diastereomers).

HRMS (ESI): $m / z[\mathrm{M}+\mathrm{Na}]^{+}$calcd for $\mathrm{C}_{10} \mathrm{H}_{19} \mathrm{NNaO}$ : 192.1359; found: 192.1356 .

\section{4-Hydroxypentanamide (3da)}

Pale-yellow oil; yield: $9.5 \mathrm{mg}$ (81\%); $R_{f}=0.25\left(\mathrm{CH}_{2} \mathrm{Cl}_{2} / \mathrm{MeOH}, 10: 1\right)$. IR $\left(\mathrm{CH}_{2} \mathrm{Cl}_{2}\right): 3347,2968,2928,1663,1411,1068,762 \mathrm{~cm}^{-1}$.

${ }^{1} \mathrm{H}$ NMR (400 MHz, CD $\mathrm{CN}_{3}$ ): $\delta=6.84$ (br s, $1 \mathrm{H}$ ), 6.24 (br s, $1 \mathrm{H}$ ), 3.93 $(\mathrm{d}, J=4.6 \mathrm{~Hz}, 1 \mathrm{H}), 3.76-3.67(\mathrm{~m}, 1 \mathrm{H}), 2.29(\mathrm{t}, J=7.6 \mathrm{~Hz}, 2 \mathrm{H}), 1.74-$ $1.56(\mathrm{~m}, 2 \mathrm{H}), 1.10(\mathrm{~d}, J=6.4 \mathrm{~Hz}, 3 \mathrm{H})$.

${ }^{13} \mathrm{C}$ NMR $\left(100 \mathrm{MHz}, \mathrm{CD}_{3} \mathrm{CN}\right): \delta=176.0,67.3,35.5,32.8,24.0$.

HRMS (ESI): $m / z$ [M + Na] $]^{+}$calcd for $\mathrm{C}_{5} \mathrm{H}_{11} \mathrm{NNaO}_{2}: 140.0682$; found: 140.0687.

\section{$\mathrm{N}$-(tert-Butyl)-4-hydroxypentanamide (3ea)}

Pale-yellow solid; yield: $10.9 \mathrm{mg}(63 \%) ; R_{f}=0.35\left(\mathrm{CH}_{2} \mathrm{Cl}_{2} / \mathrm{MeOH}\right.$, 20:1).

IR $\left(\mathrm{CH}_{2} \mathrm{Cl}_{2}\right): 3300,2967,2926,1650,1550,1454,1363,1225,1079$ $\mathrm{cm}^{-1}$.

${ }^{1} \mathrm{H}$ NMR $\left(500 \mathrm{MHz}, \mathrm{CDCl}_{3}\right): \delta=5.59(\mathrm{br} \mathrm{s}, 1 \mathrm{H}), 3.87-3.79(\mathrm{~m}, 1 \mathrm{H})$, 3.08 (br s, $1 \mathrm{H}), 2.35-2.22(\mathrm{~m}, 2 \mathrm{H}), 1.85-1.75$ (m, $1 \mathrm{H}), 1.71-1.61$ (m, $1 \mathrm{H}), 1.33(\mathrm{~s}, 9 \mathrm{H}), 1.19(\mathrm{~d}, J=6.0 \mathrm{~Hz}, 3 \mathrm{H})$.

${ }^{13} \mathrm{C} \mathrm{NMR}\left(125 \mathrm{MHz}, \mathrm{CDCl}_{3}\right): \delta=173.3,67.7,51.5,34.4,34.3,28.9,23.8$. HRMS (ESI): $m / z$ [M + Na] $]^{+}$calcd for $\mathrm{C}_{9} \mathrm{H}_{19} \mathrm{NNaO}_{2}: 196.1308$; found: 196.1315.

\section{4-Hydroxy- $\mathrm{N}$-phenylpentanamide (3fa)}

Colorless solid; yield: $11.1 \mathrm{mg}$ (58\%); $R_{f}=0.14$ ( $n$-hexane/EtOAc, 1:1). IR $\left(\mathrm{CH}_{2} \mathrm{Cl}_{2}\right): 3302,2967,2927,1663,1599,1543,1498,1443,1074$, $692 \mathrm{~cm}^{-1}$.

${ }^{1} \mathrm{H} \mathrm{NMR}\left(500 \mathrm{MHz}, \mathrm{CDCl}_{3}\right): \delta=7.72(\mathrm{br} \mathrm{s}, 1 \mathrm{H}), 7.50(\mathrm{~d}, J=7.6 \mathrm{~Hz}, 2 \mathrm{H})$, 7.31 (dd, $J=7.6,7.6 \mathrm{~Hz}, 2 \mathrm{H}$ ), 7.10 (dd, $J=7.6,7.6 \mathrm{~Hz}, 1 \mathrm{H}$ ), 3.95-3.90 (m, $1 \mathrm{H}), 2.59-2.49(\mathrm{~m}, 2 \mathrm{H}), 2.21$ (br s, $1 \mathrm{H}), 1.97-1.90(\mathrm{~m}, 1 \mathrm{H}), 1.81-$ $1.74(\mathrm{~m}, 1 \mathrm{H}), 1.24(\mathrm{~d}, J=6.3 \mathrm{~Hz}, 3 \mathrm{H})$.

${ }^{13} \mathrm{C}$ NMR $\left(125 \mathrm{MHz}, \mathrm{CDCl}_{3}\right): \delta=172.0,138.0,129.1,124.5,120.0,67.7$, $34.4,34.2,24.0$.

HRMS (ESI): $m / z$ [M + Na] $]^{+}$calcd for $\mathrm{C}_{11} \mathrm{H}_{15} \mathrm{NNaO}_{2}: 216.0995$; found: 216.1005.

\section{4-Hydroxy- $\mathbf{N}, \mathbf{N}$-dimethylpentanamide (3ga)}

Colorless oil; yield: $7.8 \mathrm{mg}$ (54\%); $R_{f}=0.35\left(\mathrm{CH}_{2} \mathrm{Cl}_{2} / \mathrm{MeOH}, 20: 1\right)$. IR $\left(\mathrm{CH}_{2} \mathrm{Cl}_{2}\right)$ : 3408, 2965, 2929, 1628, 1401, 1265, 1125, $1072 \mathrm{~cm}^{-1}$. ${ }^{1} \mathrm{H}$ NMR (500 MHz, $\mathrm{CDCl}_{3}$ ): $\delta=3.86-3.80(\mathrm{~m}, 1 \mathrm{H}), 3.13$ (br s, $1 \mathrm{H}$ ), 3.02 (br s, 3 H), 2.96 (br s, 3 H), 2.57-2.43 (m, 2 H), 1.86-1.80 (m, 1 H), $1.78-1.71(\mathrm{~m}, 1 \mathrm{H}), 1.20(\mathrm{~d}, J=6.3 \mathrm{~Hz}, 3 \mathrm{H})$.

${ }^{13} \mathrm{C}$ NMR $\left(125 \mathrm{MHz}, \mathrm{CDCl}_{3}\right): \delta=174.0,67.9,37.6,35.8$, 33.6, 30.3, 23.9. HRMS (ESI): $m / z[\mathrm{M}+\mathrm{Na}]^{+}$calcd for $\mathrm{C}_{7} \mathrm{H}_{15} \mathrm{NNaO}_{2}: 168.0995$; found: 168.0994 .

\section{5-Pentyldihydrofuran-2(3H)-one (3he)}

Colorless oil; yield: $14.0 \mathrm{mg}(90 \%) ; R_{f}=0.24$ ( $n$-hexane/EtOAc, 5:1). IR $\left(\mathrm{CH}_{2} \mathrm{Cl}_{2}\right): 2933,2861,1775,1460,1182,1021 \mathrm{~cm}^{-1}$.
${ }^{1} \mathrm{H}$ NMR $\left(500 \mathrm{MHz}, \mathrm{CDCl}_{3}\right): \delta=4.51-4.45(\mathrm{~m}, 1 \mathrm{H}), 2.54-2.51(\mathrm{~m}, 2 \mathrm{H})$, 2.35-2.28 (m, $1 \mathrm{H}), 1.89-1.81(\mathrm{~m}, 1 \mathrm{H}), 1.77-1.70(\mathrm{~m}, 1 \mathrm{H}), 1.62-1.55$ $(\mathrm{m}, 1 \mathrm{H}), 1.50-1.25(\mathrm{~m}, 6 \mathrm{H}), 0.89(\mathrm{t}, J=7.2 \mathrm{~Hz}, 3 \mathrm{H})$.

${ }^{13} \mathrm{C}$ NMR $\left(125 \mathrm{MHz}, \mathrm{CDCl}_{3}\right): \delta=177.4,81.2,35.7,31.6,29.0,28.2,25.0$, 22.6, 14.1 .

HRMS (ESI): $m / z[\mathrm{M}+\mathrm{Na}]^{+}$calcd for $\mathrm{C}_{9} \mathrm{H}_{16} \mathrm{NaO}_{2}: 179.1043$; found: 179.1049

\section{3-Methyl-5-pentyldihydrofuran-2(3H)-one (3ie)}

Obtained as inseparable diastereomers $(\mathrm{dr}=1: 2.5)$.

Colorless oil; yield: $14.5 \mathrm{mg}(85 \%) ; R_{f}=0.31$ ( $n$-hexane/EtOAc, 5:1).

IR $\left(\mathrm{CH}_{2} \mathrm{Cl}_{2}\right): 2933,2862,1771,1457,1378,1189,1011,926 \mathrm{~cm}^{-1}$.

${ }^{1} \mathrm{H}$ NMR $\left(400 \mathrm{MHz}, \mathrm{CDCl}_{3}\right): \delta$ (major diastereomer) $=4.36-4.29(\mathrm{~m}, 1$ H), 2.73-2.60 (m, $1 \mathrm{H}), 2.51-2.44(\mathrm{~m}, 1 \mathrm{H}), 1.78-1.25(\mathrm{~m}, 12 \mathrm{H}), 0.89$ $(\mathrm{t}, J=6.9 \mathrm{~Hz}, 3 \mathrm{H})$.

${ }^{1} \mathrm{H}$ NMR (400 MHz, $\left.\mathrm{CDCl}_{3}\right): \delta$ (minor diastereomer) $=4.53-4.46(\mathrm{~m}, 1$ H), 2.73-2.60 (m, $1 \mathrm{H}), 2.17-2.07(\mathrm{~m}, 1 \mathrm{H}), 2.02-1.95(\mathrm{~m}, 1 \mathrm{H}), 1.78-$ $1.25(\mathrm{~m}, 11 \mathrm{H}), 0.89(\mathrm{t}, J=6.9 \mathrm{~Hz}, 3 \mathrm{H})$.

${ }^{13} \mathrm{C}$ NMR $\left(125 \mathrm{MHz}, \mathrm{CDCl}_{3}\right): \delta=180.3,179.8,78.9,78.6,37.5,36.1$, 35.6, 35.6, 35.5, 34.2, 31.7, 31.6, 25.2, 25.1, 22.6, 16.0, 15.3, 14.1 (two methylene carbon signals overlap with those of the diastereomers).

HRMS (ESI): $m / z[\mathrm{M}+\mathrm{Na}]^{+}$calcd for $\mathrm{C}_{10} \mathrm{H}_{18} \mathrm{NaO}_{2}$ : 193.1199; found: 193.1205.

\section{5-Methyl-3-phenyldihydrofuran-2(3H)-one (3ja)}

Obtained as inseparable diastereomers ( $\mathrm{dr}=1: 2.9)$.

Colorless oil; yield: $13.8 \mathrm{mg}$ (78\%); $R_{f}=0.27$ ( $n$-hexane/EtOAc, 5:1).

IR $\left(\mathrm{CH}_{2} \mathrm{Cl}_{2}\right)$ : 2979, 2933, 1769, 1455, 1388, 1175, 1119, 1053, 949, $753,698 \mathrm{~cm}^{-1}$.

${ }^{1} \mathrm{H}$ NMR (400 MHz, $\left.\mathrm{CDCl}_{3}\right): \delta$ (major diastereomer) $=7.40-7.34(\mathrm{~m}, 2$ H), 7.32-7.27 (m, $3 \mathrm{H}), 4.68-4.59(\mathrm{~m}, 1 \mathrm{H}), 3.90(\mathrm{dd}, J=12.8,8.7 \mathrm{~Hz}, 1$ H), 2.79 (ddd, $J=12.8,8.7,5.5 \mathrm{~Hz}, 1 \mathrm{H}$ ), 2.03 (ddd, $J=12.8,12.8,10.8$ $\mathrm{Hz}, 1 \mathrm{H}), 1.51(\mathrm{~d}, J=6.4 \mathrm{~Hz}, 3 \mathrm{H})$.

${ }^{1} \mathrm{H}$ NMR $\left(400 \mathrm{MHz}, \mathrm{CDCl}_{3}\right)$ : $\delta$ (minor diastereomer) $=7.40-7.34(\mathrm{~m}, 2$ H), 7.32-7.27 (m, $3 \mathrm{H}), 4.85-4.77(\mathrm{~m}, 1 \mathrm{H}), 3.94$ (dd, $J=9.6,7.3 \mathrm{~Hz}, 1$ H), 2.55 (ddd, $J=13.3,7.3,7.3 \mathrm{~Hz}, 1 \mathrm{H}$ ), 2.36 (ddd, $J=13.3,9.6,6.0 \mathrm{~Hz}$, $1 \mathrm{H}), 1.47(\mathrm{~d}, J=6.4 \mathrm{~Hz}, 3 \mathrm{H})$.

${ }^{13} \mathrm{C}$ NMR $\left(125 \mathrm{MHz}, \mathrm{CDCl}_{3}\right): \delta=177.3,177.0,137.2,136.7,129.1$, 129.0, 128.2, 127.8, 127.7, 127.7, 75.3, 75.1, 47.8, 45.8, 39.9, 38.1, 21.2, 21.0 .

HRMS (ESI): $m / z[\mathrm{M}+\mathrm{Na}]^{+}$calcd for $\mathrm{C}_{11} \mathrm{H}_{12} \mathrm{NaO}_{2}$ : 199.0730; found: 199.0732 .

\section{4-(Phenylsulfonyl)butan-2-ol (3ka)}

Colorless oil; yield: $16.2 \mathrm{mg}$ (76\%); $R_{f}=0.23$ ( $n$-hexane/EtOAc, 1:1). IR $\left(\mathrm{CH}_{2} \mathrm{Cl}_{2}\right)$ : 3494, 2969, 2928, 1447, 1303, 1145, 1086, 743, $688 \mathrm{~cm}^{-1}$. ${ }^{1} \mathrm{H}$ NMR $\left(400 \mathrm{MHz}, \mathrm{CDCl}_{3}\right): \delta=7.94-7.91(\mathrm{~m}, 2 \mathrm{H}), 7.67$ (dddd, $J=7.6$, 7.6, 1.4, 1.4 Hz, $1 \mathrm{H}), 7.60-7.56(\mathrm{~m}, 2 \mathrm{H}), 3.97-3.89$ ( $\mathrm{m}, 1 \mathrm{H}), 3.34-3.17$ (m, $2 \mathrm{H}), 1.99-1.90(\mathrm{~m}, 1 \mathrm{H}), 1.83-1.74(\mathrm{~m}, 1 \mathrm{H}), 1.21(\mathrm{~d}, J=6.4 \mathrm{~Hz}, 3$ $\mathrm{H})$.

${ }^{13} \mathrm{C}$ NMR $\left(125 \mathrm{MHz}, \mathrm{CDCl}_{3}\right): \delta=139.2,133.9,129.5,128.1,66.3,53.2$, 31.7, 23.8 .

HRMS (ESI): $m / z[\mathrm{M}+\mathrm{Na}]^{+}$calcd for $\mathrm{C}_{10} \mathrm{H}_{14} \mathrm{NaO}_{3} \mathrm{~S}: 237.0556$; found: 237.0556 . 
Methyl (S)-2-\{[(Benzyloxy)carbonyl]amino\}-5-(diethoxyphosphoryl)-3-hydroxypentanoate (3al)

Obtained as inseparable diastereomers $(\mathrm{dr}=1: 4)$.

Pale-yellow oil; yield: $14.2 \mathrm{mg}$ (34\%); $R_{f}=0.46\left(\mathrm{CH}_{2} \mathrm{Cl}_{2} / \mathrm{MeOH}, 10: 1\right)$. IR $\left(\mathrm{CH}_{2} \mathrm{Cl}_{2}\right)$ : 3357, 2983, 1751, 1724, 1533, 1439, 1211, 1054, 1026, $965,749,699 \mathrm{~cm}^{-1}$.

${ }^{1} \mathrm{H} \mathrm{NMR}\left(400 \mathrm{MHz}, \mathrm{CDCl}_{3}\right): \delta=7.36-7.28(\mathrm{~m}, 5 \mathrm{H}$ ), 5.93 (br d, $J=9.6$ $\mathrm{Hz}, 1 \mathrm{H}), 5.15-5.08(\mathrm{~m}, 2 \mathrm{H}), 4.36$ (dd, $J=9.6,2.3 \mathrm{~Hz}, 1 \mathrm{H}), 4.19-4.18$ (m, $1 \mathrm{H}), 4.13-4.01(\mathrm{~m}, 4 \mathrm{H}), 3.76(\mathrm{~s}, 3 \mathrm{H}), 1.92-1.78(\mathrm{~m}, 4 \mathrm{H}), 1.32-$ $1.25(\mathrm{~m}, 6 \mathrm{H})$.

${ }^{13} \mathrm{C}$ NMR $\left(125 \mathrm{MHz}, \mathrm{CDCl}_{3}\right): \delta$ (major diastereomer) $=171.5,156.9$, $136.4,128.7,128.3,128.2,71.8(\mathrm{~d}, J=11.9 \mathrm{~Hz}), 67.3,62.3(\mathrm{~d}, J=6.0$ $\mathrm{Hz}), 62.1(\mathrm{~d}, J=6.0 \mathrm{~Hz}), 58.7,52.7,27.2(\mathrm{~d}, J=4.8 \mathrm{~Hz}), 22.5(\mathrm{~d}, J=140.7$ $\mathrm{Hz}), 16.5(\mathrm{~d}, J=6.0 \mathrm{~Hz})$.

${ }^{13} \mathrm{C}$ NMR (125 MHz, $\mathrm{CDCl}_{3}$ ): $\delta$ (minor diastereomer) $=170.7,156.5$, $136.2,128.7,128.6,128.4,72.8$ (d, $J=11.9 \mathrm{~Hz}), 67.4,62.0$ (d, $J=6.0$ $\mathrm{Hz}$ ), 58.8, 52.6, $26.6(\mathrm{~d}, J=4.8 \mathrm{~Hz}), 22.4(\mathrm{~d}, J=141.9 \mathrm{~Hz}), 16.5$ (d, $J=6.0$ $\mathrm{Hz}$ ) (two doublet signals of the minor diastereomer overlap with those of the major diastereomer).

${ }^{31} \mathrm{P}$ NMR (159 MHz, $\mathrm{CDCl}_{3}$ ): $\delta=32.3$ (major diastereomer), 32.2 (minor diastereomer).

HRMS (ESI): $m / z[\mathrm{M}+\mathrm{Na}]^{+}$calcd for $\mathrm{C}_{18} \mathrm{H}_{28} \mathrm{NNaO}_{8} \mathrm{P}: 440.1445$; found: 440.1438 .

\section{tert-Butyl (2-\{[(Benzyloxy)carbonyl]amino\}-6-(diethoxyphos-} phoryl)-4-hydroxyhexanoyl)glycinate (3am)

Obtained as inseparable diastereomers $(\mathrm{dr}=1: 1)$.

Colorless oil; yield: $39.6 \mathrm{mg}$ (75\%); $R_{f}=0.58\left(\mathrm{CH}_{2} \mathrm{Cl}_{2} / \mathrm{MeOH}, 10: 1\right)$.

IR $\left(\mathrm{CH}_{2} \mathrm{Cl}_{2}\right): 3315,2980,2933,1725,1677,1528,1368,1226,1157$, $1028,965 \mathrm{~cm}^{-1}$.

${ }^{1} \mathrm{H}$ NMR (500 MHz, $\mathrm{CDCl}_{3}$ ): $\delta=7.35-7.29(\mathrm{~m}, 5 \mathrm{H}$ ), 7.18 (br s, $0.5 \mathrm{H}$ ), 7.01 (br s, $0.5 \mathrm{H}$ ), 6.29 (br d, $J=8.0 \mathrm{~Hz}, 0.5 \mathrm{H}$ ), 5.97 (br d, $J=6.0 \mathrm{~Hz}, 0.5$ H), $5.10+5.08(\mathrm{~s}+\mathrm{s}, 2 \mathrm{H}), 4.47(\mathrm{br} \mathrm{m}, 0.5 \mathrm{H}), 4.42-4.41(\mathrm{br} \mathrm{m}, 0.5 \mathrm{H})$, 4.13-4.01 (m, $4 \mathrm{H}), 3.97-3.92(\mathrm{~m}, 1 \mathrm{H}), 3.89-3.78$ (m, $2 \mathrm{H}), 1.95-1.69$ $(\mathrm{m}, 6 \mathrm{H}), 1.45+1.45(\mathrm{~s}+\mathrm{s}, 9 \mathrm{H}), 1.32-1.28(\mathrm{~m}, 6 \mathrm{H})$.

${ }^{13} \mathrm{C}$ NMR (125 MHz, $\mathrm{CDCl}_{3}$ ): $\delta=172.2,171.9,168.9$ (another signal may overlap this peak), $157.0,156.3,136.3,136.2,128.7,128.6,128.3$, 128.2, 128.2, 128.2, 82.5, 82.3, 68.8 (d, $J=11.9 \mathrm{~Hz}), 68.7$ (d, $J=13.1$ Hz), 67.3, 67.1, 62.0, 62.0, 61.9, 61.9, 61.9, 61.9, 53.1, 52.9, 42.1, 42.1, 40.5, 39.6, 30.3 (d, $J=4.8 \mathrm{~Hz}), 30.2(\mathrm{~d}, J=4.8 \mathrm{~Hz}), 28.2,22.4$ (d, $J=$ $140.7 \mathrm{~Hz}$ ), $22.2(\mathrm{~d}, J=140.7 \mathrm{~Hz}), 16.5(\mathrm{~d}, J=6.0 \mathrm{~Hz}$ ) (another signal may overlap this peak).

The $J$ values of the signals at $\delta=62.0-61.9$ are difficult to be determine because of overlapping with the signals of diastereomers.

${ }^{31} \mathrm{P}$ NMR (159 MHz, $\left.\mathrm{CDCl}_{3}\right): \delta=32.7,32.6$.

HRMS (ESI): $m / z$ [M + Na $]^{+}$calcd for $\mathrm{C}_{24} \mathrm{H}_{39} \mathrm{~N}_{2} \mathrm{NaO}_{9} \mathrm{P}: 553.2285$; found: 553.2285 .

\section{Funding Information}

This work was supported by the Japan Society for the Promotion of Science (JSPS) KAKENHI grants [JP19J23157 (JSPS Fellows) (to K. S.), JP18H04239 (Precisely Designed Catalysts with Customized Scaffolding), JP18K06545 (Scientific Research C) (to K.O.), and JP17H06442 (Hybrid Catalysis) (to M.K.)], and the TOBE MAKI Scholarship Foundation (K.S.).

\section{Supporting Information}

Supporting information for this article is available online at https://doi.org/10.1055/s-0040-1707114.

\section{References}

(1) (a) Yamaguchi, J.; Yamaguchi, A. D.; Itami, K. Angew. Chem. Int. Ed. 2012, 51, 8960. (b) Wencel-Delord, J.; Glorius, F. Nat. Chem. 2013, 5, 369. (c) Cernak, T.; Dykstra, K. D.; Tyagarajan, S.; Vachal, P.; Krska, S. W. Chem. Soc. Rev. 2016, 45, 546.

(2) For recent reviews on $\mathrm{C}\left(\mathrm{sp}^{3}\right)-\mathrm{H}$ functionalization reactions, see: (a) He, J.; Wasa, M.; Chan, K. S. L.; Shao, Q.; Yu, J.-Q. Chem. Rev. 2017, 117, 8754. (b) Lu, Q.; Glorius, F. Angew. Chem. Int. Ed. 2017, 56, 49. (c) Liu, C.; Yuan, J.; Gao, M.; Tang, S.; Li, W.; Shi, R.; Lei, A. Chem. Rev. 2015, 115, 12138. (d) Xie, J.; Pan, C.; Abdukader, A.; Zhu, C. Chem. Soc. Rev. 2014, 43, 5245. (e) Gensch, T.; Hopkinson, M. N.; Glorius, F.; Wencel-Delord, J. Chem. Soc. Rev. 2016, 45, 2900. (f) Matsui, J. K.; Lang, S. B.; Heitz, D. R.; Molander, G. A. ACS Catal. 2017, 7, 2563. (g) Yi, H.; Zhang, G.; Wang, H.; Huang, Z.; Wang, J.; Singh, A. K.; Lei, A. Chem. Rev. 2017, 117, 9016. (h) Chen, Z.; Rong, M.-Y.; Nie, J.; Zhu, X.-F.; Shi, B.-F.; Ma, J.-A. Chem. Soc. Rev. 2019, 48, 4921.

(3) Lovering, F.; Bikker, J.; Humblet, C. J. Med. Chem. 2009, 52, 6752.

(4) For reviews on $\mathrm{C}\left(\mathrm{sp}^{3}\right)-\mathrm{H}$ functionalization reactions via the HAT mechanism under irradiation with visible light, see: (a) Shaw, M. H.; Twilton, J.; MacMillan, D. W. C. J. Org. Chem. 2016, 81, 6898. (b) Capaldo, L.; Ravelli, D. Eur. J. Org. Chem. 2017, 2056. (c) Hu, X.-Q.; Chen, J.-R.; Xiao, W.-J. Angew. Chem. Int. Ed. 2017, $56,1960$.

(5) (a) Tanaka, H.; Sakai, K.; Kawamura, A.; Oisaki, K.; Kanai, M. Chem. Commun. 2018, 54, 3215. (b) Wakaki, T.; Sakai, K.; Enomoto, T.; Kondo, M.; Masaoka, S.; Oisaki, K.; Kanai, M. Chem. Eur. J. 2018, 24, 8051. (c) Sakai, K.; Oisaki, K.; Kanai, M. Adv. Synth. Catal. 2020, 362, 337. (d) Kato, S.; Saga, Y.; Kojima, M.; Fuse, H.; Matsunaga, S.; Fukatsu, A.; Kondo, M.; Masaoka, S.; Kanai, M. J. Am. Chem. Soc. 2017, 139, 2204. (e) Fuse, H.; Kojima, M.; Mitsunuma, H.; Kanai, M. Org. Lett. 2018, 20, 2042.

(6) (a) Estes, D. P.; Grills, D. C.; Norton, J. R. J. Am. Chem. Soc. 2014, 136, 17362. (b) Roth, J. P.; Mayer, J. M. Inorg. Chem. 1999, 38, 2760. (c) Wu, A.; Mayer, J. M. J. Am. Chem. Soc. 2008, 130, 14745. (d) Manner, V. M.; Mayer, J. M. J. Am. Chem. Soc. 2009, 131, 9874. (e) Jonas, R. T.; Stack, T. D. P. J. Am. Chem. Soc. 1997, 119, 8566. (f) Semproni, S. P.; Milsmann, C.; Chirik, P. J. J. Am. Chem. Soc. 2014, 136, 9211. (g) Milsmann, C.; Semproni, S. P.; Chirik, P. J. J. Am. Chem. Soc. 2014, 136, 12099. (h) Bezdek, M. J.; Guo, S.; Chirik, P. J. Science 2016, 354, 730. (i) Fang, H.; Ling, Z.; Lang, K.; Brothers, P. J.; de Bruin, B.; Fu, X. Chem. Sci. 2014, 5, 916. (j) Miyazaki, S.; Kojima, T.; Mayer, J. M.; Fukuzumi, S. J. Am. Chem. Soc. 2009, 131, 11615. (k) Resa, S.; Millán, A.; Fuentes, N.; Crovetto, L.; Marcos, M. L.; Lezama, L.; Choquesillo-Lazarte, D.; Blanco, V.; Campaña, A. G.; Cárdenas, D. J.; Cuerva, J. M. Dalton Trans. 2019, 48, 2179.

(7) (a) Spiegel, D. A.; Wiberg, K. B.; Schacherer, L. N.; Medeiros, M. R.; Wood, J. L. J. Am. Chem. Soc. 2005, 127, 12513. (b) Pozzi, D.; Scanlan, E. M.; Renaud, P. J. Am. Chem. Soc. 2005, 127, 14204. (c) Chciuk, T. V.; Flowers, R. A. II. J. Am. Chem. Soc. 2015, 137, 11526.

(8) Tarantino, K. T.; Miller, D. C.; Callon, T. A.; Knowles, R. R. J. Am. Chem. Soc. 2015, 137, 6440. 
(9) (a) Jeffrey, J. L.; Terrett, J. A.; MacMillan, D. W. C. Science 2015 , 349, 1532. (b) Wan, I. C. (S.); Witte, M. D.; Minnaard, A. J. Chem. Commun. 2017, 53, 4926. (c) Wang, Y.; Carder, H. M.; Wendlandt, A. E. Nature 2020, 578, 403. (d) For related discussions on the bond-weakening of alcohols through hydrogen bonding, see: Gawlita, E.; Lantz, M.; Paneth, P.; Bell, A. F.; Tonge, P. J.; Anderson, V. E. J. Am. Chem. Soc. 2000, 122, 11660.

(10) (a) Dimakos, V.; Su, H. Y.; Garrett, G. E.; Taylor, M. S. J. Am. Chem. Soc. 2019, 141, 5149. (b) Dimakos, V.; Gorelik, D.; Su, H. Y.; Garrett, G. E.; Hughes, G.; Shibayama, H.; Taylor, M. S. Chem. Sci. 2020, 11, 1531.

(11) Perozzi, E. F.; Martin, J. C. J. Am. Chem. Soc. 1979, 101, 1591.

(12) For details, see the Supporting Information.

(13) Lowry, M. S.; Goldsmith, J. I.; Slinker, J. D.; Rohl, R.; Pascal, R. A.; Malliaras, G. G.; Bernhard, S. Chem. Mater. 2005, 17, 5712.

(14) For representative examples of quinuclidine acting as a HAT catalyst, see: (a) Shaw, M. H.; Shurtleff, V. W.; Terrett, J. A.; Cuthbertson, J. D.; MacMillan, D. W. C. Science 2016, 352, 1304. (b) Le, C.; Liang, Y.; Evans, R. W.; Li, X.; MacMillan, D. W. C. Nature 2017, 547, 79. (c) Zhang, X.; MacMillan, D. W. C. J. Am. Chem. Soc. 2017, 139, 11353.

(15) Lima, F.; Sharma, U. K.; Grunenberg, L.; Saha, D.; Johannsen, S.; Sedelmeier, J.; Van der Eycken, E. V.; Ley, S. V. Angew. Chem. Int. Ed. 2017, 56, 15136.
(16) Ishihara, K.; Yamamoto, H. Eur. J. Org. Chem. 1999, 527.

(17) (a) Farfán, N.; Castillo, D.; Joseph-Nathan, P.; Contreras, R.; Szetpály, L. v. J. Chem. Soc., Perkin Trans. 2 1992, 527. (b) Marciasini, L.; Cacciuttolo, B.; Vaultier, M.; Pucheault, M. Org. Lett. 2015, 17, 3532.

(18) Joshi-Pangu, A.; Lévesque, F.; Roth, H. G.; Oliver, S. F.; Campeau, L.-C.; Nicewicz, D.; DiRocco, D. A. J. Org. Chem. 2016, 81, 7244.

(19) Fukuzumi, S.; Kotani, H.; Ohkubo, K.; Ogo, S.; Tkachenko, N. V.; Lemmetyinen, H. J. Am. Chem. Soc. 2004, 126, 1600.

(20) Choi, G. J.; Zhu, Q.; Miller, D. C.; Gu, C. J.; Knowles, R. R. Nature 2016, 539, 268.

(21) Yang, H.-B.; Feceu, A.; Martin, D. B. C. ACS Catal. 2019, 9, 5708.

(22) Mukherjee, S.; Maji, B.; Tlahuext-Aca, A.; Glorius, F. J. Am. Chem. Soc. 2016, 138, 16200.

(23) The $\mathrm{C}-\mathrm{H}$ alkylation of $\mathbf{2} \mathbf{j}$ and $\mathbf{2 k}$ without borinate catalyst $\mathbf{6 \mathbf { j }}$ proceeded in yields that were too low to determine the siteselectivity.

(24) Nelsen, S. F.; Hintz, P. J. J. Am. Chem. Soc. 1972, 94, 7114.

(25) Liu, W.-Z.; Bordwell, F. G. J. Org. Chem. 1996, 61, 4778.

(26) The increase in the chemical yield may also partially originate from electrostatic interactions between the anionic borate and the quinuclidinium radical cation. For a related discussion, see: Ye, J.; Kalvet, I.; Schoenebeck, F.; Rovis, T. Nat. Chem. 2018, 10, 1037. 